\title{
Review \\ Failure to Guard: Mitochondrial Protein Quality Control in Cancer
}

\author{
Joseph E. Friedlander ${ }^{1,+}$, Ning Shen ${ }^{1,2,+}$, Aozhuo Zeng ${ }^{1}$, Sovannarith Korm ${ }^{1}$ (D) and Hui Feng ${ }^{1,2, *(D)}$ \\ 1 Department of Pharmacology and Experimental Therapeutics, Boston University School of Medicine, \\ Boston, MA 02118, USA; jfriedla@bu.edu (J.E.F.); shenning@bu.edu (N.S.); az5@bu.edu (A.Z.); \\ ksnarith07@gmail.com (S.K.) \\ 2 Department of Medicine, Section of Hematology and Medical Oncology, Boston University School of \\ Medicine, Boston, MA 02118, USA \\ * Correspondence: huifeng@bu.edu; Tel.: +1-617-358-4688; Fax: +1-617-358-1599 \\ + Equal contribution.
}

check for updates

Citation: Friedlander, J.E.; Shen, N.; Zeng, A.; Korm, S.; Feng, H. Failure to Guard: Mitochondrial Protein Quality Control in Cancer. Int. J. Mol. Sci. 2021, 22, 8306. https://doi.org/ $10.3390 /$ ijms 22158306

Academic Editors: Jaroslav Truksa and Cristian Sandoval Acuna

Received: 4 July 2021

Accepted: 27 July 2021

Published: 2 August 2021

Publisher's Note: MDPI stays neutral with regard to jurisdictional claims in published maps and institutional affiliations.

Copyright: (c) 2021 by the authors. Licensee MDPI, Basel, Switzerland This article is an open access article distributed under the terms and conditions of the Creative Commons Attribution (CC BY) license (https:// creativecommons.org/licenses/by/ $4.0 /)$.

\begin{abstract}
Mitochondria are energetic and dynamic organelles with a crucial role in bioenergetics, metabolism, and signaling. Mitochondrial proteins, encoded by both nuclear and mitochondrial DNA, must be properly regulated to ensure proteostasis. Mitochondrial protein quality control (MPQC) serves as a critical surveillance system, employing different pathways and regulators as cellular guardians to ensure mitochondrial protein quality and quantity. In this review, we describe key pathways and players in MPQC, such as mitochondrial protein translocation-associated degradation, mitochondrial stress responses, chaperones, and proteases, and how they work together to safeguard mitochondrial health and integrity. Deregulated MPQC leads to proteotoxicity and dysfunctional mitochondria, which contributes to numerous human diseases, including cancer. We discuss how alterations in MPQC components are linked to tumorigenesis, whether they act as drivers, suppressors, or both. Finally, we summarize recent advances that seek to target these alterations for the development of anti-cancer drugs.
\end{abstract}

Keywords: mitochondria; MPQC; proteostasis; chaperone; protease; cancer; tumorigenesis; oncogene; tumor suppressor; therapeutic targeting

\section{Introduction}

Long known as the powerhouse of the cell, mitochondria are the central hub of cellular metabolism, homeostasis, and stress responses, regulating cell growth, division, differentiation, and death [1,2]. In humans, mitochondria are passed down to offspring through the fertilized egg, with the initial mitochondrial DNA (mtDNA) primarily derived from the mother [3,4]. Mitochondria contain an outer (OMM) and an inner (IMM) membrane, facilitating the formation of two aqueous compartments: the intermembrane space (IMS) and the matrix (Figure 1). Nuclear DNA (nDNA) encodes approximately $99 \%$ of mitochondrial proteins with the remaining $1 \%$ from mtDNA [5]. Most oxidative phosphorylation (OXPHOS) components and the proteins required for metabolism and biogenesis are transcribed in the nucleus, subsequently translated by ribosomes in the cytosol, and finally imported into mitochondria for proper folding and assembly [6]. The remaining 13 transmembrane components of OXPHOS, which are encoded by mtDNA, are transcribed and translated in the mitochondrial matrix, and then assembled and inserted into the IMM [7].

Since proteins in mitochondria are derived from different cellular compartments, they face a unique set of challenges to maintain homeostasis. Compared to the cytosol, mitochondria possess higher reductive potentials, $\mathrm{pH}$, and temperature [8]. Mitochondrial proteins are prone to errors during folding and assembly due to oxidative stress and post-translational modifications [9-13]. To maintain proteostasis, the cell exploits the mitochondrial protein quality control (MPQC) machineries to prevent, correct, and eliminate 
the mistranslated, mislocated, and/or misfolded proteins. A compromised MPQC often leads to mitochondrial dysfunction, which is commonly associated with human diseases including cancer [14]. An in-depth knowledge of MPQC is crucial to elucidate disease pathogenesis, especially tumorigenesis.

Cancer is one of the leading causes of death worldwide. Among the hallmarks of cancer, altered mitochondrial functions contribute to cancer initiation, progression, and treatment resistance [14]. Mitochondrial dysfunction can result from genetic mutations in nDNA and mtDNA, defects in gene transcription, mistakes in protein translation and import, or errors in post-translational modifications $[15,16]$. In the past three decades, significant efforts have been employed to investigate the role of MPQC in maintaining mitochondrial integrity and the pathologic consequences due to its disruption. Alterations of the MPQC pathways have been detected in various types of cancer, with some attributed to tumorigenesis [17]. Here, we summarize current knowledge on mitochondrial proteostasis and its quality control systems, with a focus on how the dysregulation of these processes contributes to tumor development and the potential to exploit this knowledge for therapeutic intervention.

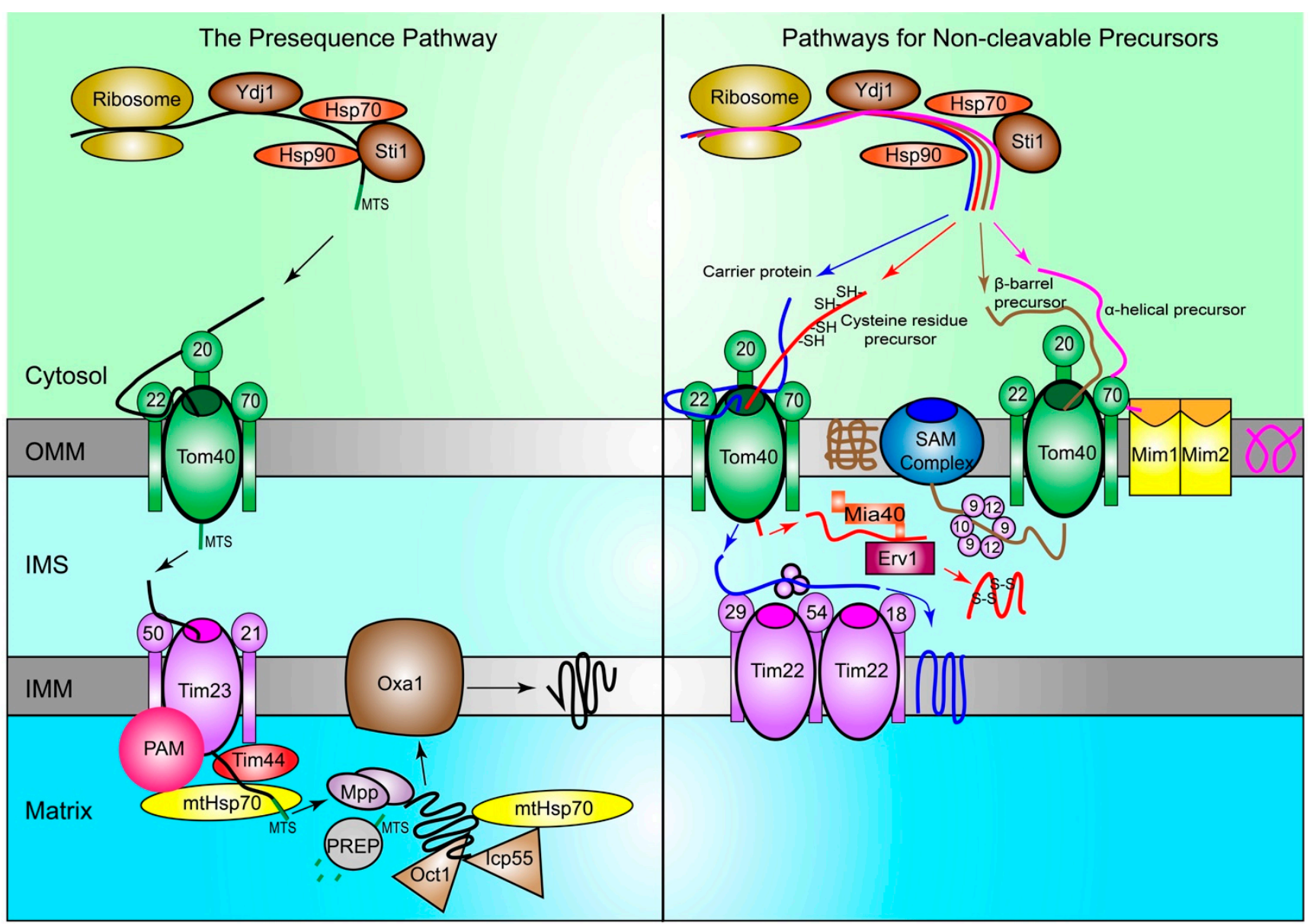

Figure 1. Proteins are imported into mitochondria through multiple pathways. In yeast, protein precursors are synthesized by ribosomes in the cytosol and guided to the TOM complex on the OMM by chaperone Hsp70 and Hsp90, with the help of co-chaperones Ydj1 and Sti1. In the presequence pathway (left), precursors are first recognized by Tom 20 of the TOM complex in the cytosol. Then, precursors are handed to Tom 22 and subsequently brought through the Tom 40 channel into the IMS. They are received by Tim50 of the TIM23 complex on the IMM and passed through to the matrix, with the help of the Tim44 protein and mtHsp70. The PAM complex prevents precursors from moving backwards out of the TIM23 complex. MPP cleaves the MTS to release proteins. Icp55 and Oct1 help remove any unstable amino acids from the N-terminal cleavage site of the proteins. Then, the presequence is degraded by PREP, and Oxa1 helps integrate mature proteins into the 
IMM when needed. In the pathways for non-cleavable proteins (right), carrier proteins (blue), proteins with cysteine residues (red), $\alpha$-helical (purple), and $\beta$-barrel (brown) are shown. Carrier proteins pass through the TOM complex via the Tom 40 channel into the IMS. Then, they are carried to their final location in the IMM by the TIM22 complex and other IMS chaperones. Precursors with cysteine residues also pass through the TOM complex via the Tom 40 channel. Then, they are received by Mia40, which is regulated by Erv1, and helps create the disulfide bonds between cysteine residues and form mature proteins. $\alpha$-helical precursors rely on Tom70 for recognition and do not localize to the IMS, as they are integrated into the OMM by the MIM complex. $\beta$-barrel precursors pass through the Tom 40 pore into the IMS, and then moved to the SAM complex on the OMM via Tim chaperones, including Tim9, Tim10, and Tim12. Then, the SAM complex incorporates the mature proteins into the OMM. TOM: translocase of the outer membrane; OMM: Outer mitochondrial membrane; Hsp70: Heat-shock protein 70; Hsp90: Heat-shock protein 90; Ydj1: Yeast dnaJ 1; Sti1: Stress inducible protein 1; IMS: Intermembrane space; TIM: translocase of the inner membrane; IMM: Inner mitochondrial membrane; PAM: Presequence translocase-associated motor; MPP: Mitochondrial processing peptidase; MTS: Mitochondrial targeting sequence; Icp55: Intermediate cleaving peptidase 55; Oct1: Octapeptidyl aminopeptidase; PREP: Presequence peptidase; Oxa1: Mitochondrial inner membrane protein OXA1; Mia40: Mitochondrial intermembrane space import and assembly protein 40; Erv1: FAD-linked sulfhydryl oxidase ERV1; MIM: mitochondrial import complex; SAM: Sorting and assembly machinery.

\section{The ORIGIN of Mitochondrial Proteins}

Mitochondria in eukaryotes are commonly believed to arise from the engulfment of an aerobic prokaryote by a single-cell organism with a nucleus, under the rising levels of oxygen in the Earth's atmosphere and the need for symbiosis between early anaerobic and aerobic organisms [18,19]. Upon being engulfed, the aerobic organism's genes were kept separately (i.e., mtDNA inside the mitochondria) to maintain the proper localization of their encoded proteins, which are highly hydrophobic [20].

\subsection{Mitochondrial Proteins Encoded by $n D N A$}

In humans, nearly 1500 mitochondrial proteins are translated by cytosolic ribosomes from mRNA encoded by nDNA [21]. These ribosomes reside in the vicinity of the OMM or near contact sites between the mitochondria and the endoplasmic reticulum (ER) [22,23]. During protein transport from cytosol to mitochondria, chaperones and co-chaperones play a critical role to prevent the misfolding or damage of mitochondrial precursor proteins [24]. Co-chaperones, including Yeast dnaJ 1 (Ydj1; the homolog of human heat-shock protein 40 (HSP40)), first target unfolded precursor proteins, which are subsequently transferred to Hsp70 and then to Hsp90 [25,26]. This transfer step is also facilitated by the co-chaperone stress inducible protein 1 (Sti1), the yeast homolog of HSP70/HSP90 organizing protein, leading the precursors to the translocase of the outer membrane (TOM) complex (Figure 1) [27-31]. Mistakes during this process can trigger the degradation of these precursors by the cytosolic ubiquitin-proteasome system [32]. The transport of these precursors, those with and without a cleavable presequence, from cytosolic ribosomes to mitochondria is summarized below.

\subsubsection{The Presequence Pathway}

Precursor proteins with an N-terminal mitochondrial targeting sequence (MTS) make up more than $60 \%$ of mitochondrial proteins and utilize the presequence pathway (Figure 1) [21,33]. The chaperones and co-chaperones in the cytosol bind to precursors to prevent their folding and facilitate their recognition by Tom 20 of the TOM complex on the OMM [26]. Then, these precursors with the MTS presequence, which is positively charged, are handed to the central receptor, Tom22, and driven inward by the mitochondrial membrane potential and the negative charges inside the mitochondrial matrix [26,33,34].

Subsequently, precursors pass through the Tom 40 pore and are moved to the translocase of the inner membrane 50 (Tim50), which is a subunit of the TIM23 complex in the IMM. The next step is to transfer precursors from Tim23 to the presequence translocase-associated motor (PAM) via the coupling activity of Tim44 [34]. PAM helps move precursors into the matrix, thus preventing them from returning to the cytosol [6]. Then, precursors are driven 
through the IMM, facilitated by the high membrane potential and the ATP-dependent actions of the mitochondrial Hsp70 (mtHsp70) [32]. Then, the MTS presequence is cleaved by the mitochondrial processing peptidase (MPP) as mitochondrial chaperones stabilize the premature protein [35]. Intermediate cleaving peptidase 55 (Icp55) and octapeptidyl aminopeptidase (Oct1) remove any unstable amino acids from the $\mathrm{N}$-terminal cleavage site of the premature protein [34]. The cleaved N-terminal MTS presequence is subsequently degraded by the matrix peptidasome, presequence peptidase (PREP) [36], as chaperones within the matrix, such as mtHsp70, help with further folding and maturation of the protein [34]. If the destination of the precursor is not in the matrix, the translocase Oxa1 inserts it into the IMM [37].

\subsubsection{Pathways for Non-Cleavable Precursors}

Precursors that are non-cleavable include carrier proteins as well as those with cysteine residues, $\alpha$-helixes, or $\beta$-barrels (Figure 1). After they are synthesized in cytosol, carrier precursors are first recognized by Tom70 and then handed over to the general central receptor Tom 22 before passing through the Tom 40 pore [6]. The Tim 22 complex receives these precursors through their interaction with the Tim 29 subunit $[38,39]$. The Tim22 complex binds to carrier precursors and guides them to their destination typically via small Tim chaperones in the IMS, which inserts them into the IMM when the membrane potential is high $[31,39,40]$.

The recognition of precursors with cysteine residues is facilitated by the mitochondrial intermembrane space import and assembly protein 40 (Mia40) after the precursors pass through the Tom 40 pore. Mia40 aids in the formation of the disulfide bonds between cysteine residues during protein folding [26], which is crucial for the proper import and assembly of these precursors in the IMS [41]. The function of Mia40 is mediated by its reduction and oxidation through the sulfhydryl oxidase Erv1, which also prevents the protein from backsliding out of the mitochondria [40].

The import pathways for precursors possessing $\alpha$-helixes or $\beta$-barrels differ slightly from those with cysteine residues. $\alpha$-helical precursors, which make up more than $90 \%$ of integral proteins of the OMM, are first recognized by Tom70 but do not go through the Tom40 pore. The mitochondrial import (MIM) complex, which consists of Mim1 and Mim2, interacts with the Tom complex to integrate $\alpha$-helical precursors into the OMM [42]. $\beta$-barrel precursors are imported through the Tom 40 pore, with small Tim chaperones guiding them to the OMM-bound sorting and assembly machinery (SAM) complex. The SAM complex, specifically the Sam 50 protein, integrates $\beta$-barrel precursors into the OMM $[43,44]$.

\subsection{Mitochondrial Proteins Encoded by $m t D N A$}

Different from nDNA, mtDNA is circular and only $\approx 16.5 \mathrm{~kb}$, encoding 2 mitoribosomal RNAs (mt-rRNAs), 22 mitochondrial transfer RNAs (mt-tRNAs), and 13 hydrophobic subunits essential for OXPHOS [45]. Prior to protein biosynthesis from mtDNA, the relevant regulators encoded by nDNA must be imported into mitochondria and folded into their matured states. This process is critical for the maintenance of mtDNA, as well as the biosynthesis, modification, and stability of mt-tRNAs and mitochondrial proteins [46]. Activated auxiliary proteins, such as phosphorylated mitochondrial transcription factor A (TFAM) and mitochondrial transcription factor B2, recruit DNA-dependent RNA polymerases to initiate mtDNA transcription [47]. Then, the elongation of mitochondrial mRNA (mt-mRNA) is achieved and maintained by transcription elongation factors [48]. Upon transcriptional termination, mt-mRNA are released and processed through intron excision and polyadenylation in the matrix [49].

Protein translation in mitochondria follows the same major steps as that in cytosol: initiation, elongation, termination, and ribosome recycling [50]. In the matrix, mitochondrial ribosomes (i.e., mitoribosomes) translate mature mt-mRNA into functional proteins. Similar to the cytosolic ribosome, the mitoribosome possesses a large (mt-LSU) and a small (mt- 
SSU) subunit, each consisting of an aminoacyl-(A-), peptidyl-(P-), and exit-(E-) site [51,52]. However, mitoribosomes have a lower sedimentation coefficient, molecular weight, and number of associating rRNAs [53]. Due to the origin of mitochondria, the protein components of mitoribosomes are similar to those of bacteria [50].

Translation is initiated when a mitochondrial initiation factor, mtIF2 or mtIF3, binds to both the start codon of mature mt-mRNAs and the P-site in mtLSU [54]. The binding triggers the recruitment of charged mitochondrial methionyl transfer RNA (mt-tRNA ${ }^{\text {Met }}$ ) to the P-site, which symbolizes the start of translational elongation [55]. Other mitochondrial elongation factors-elongation factor $\mathrm{Tu}$, $\mathrm{Ts}$, and $\mathrm{G}$ - are subsequently recruited to the mitoribosomes to facilitate elongation [47]. All $13 \mathrm{mtDNA}$-encoded peptides have long stretches of hydrophobic residues and are destined to the IMM. To avoid the aggregation and precipitation of hydrophobic residues in the matrix, nascent peptides are inserted into the IMM as they are synthesized [56]. Similar to the presequence pathway, this cotranslational insertion is facilitated by Oxa1 insertase and mitochondrial ribosomal protein L45 on the IMM [7,37]. During translational termination, the mitochondrial release factor recognizes and binds to the stop codon of mRNA and the mitoribosomal A-site, which triggers the hydrolysis of the peptidyl-tRNA bond and subsequent exit of mature proteins from mitoribosomes. Lastly, mitoribosomal recycling factors catalyze the release of the mRNAs, tRNAs, mt-LSUs, and mt-SSUs [57,58].

Activator proteins, such as translational activator Pet309 in yeast, play a critical role in regulating mitochondrial protein synthesis [7]. These activator proteins interact with specific mt-mRNAs in the $5^{\prime}$ untranslated regions (5'-UTR) and both subunits of mitoribosomes. On the other hand, most mammalian mt-mRNA lack $5^{\prime}$-UTR. Therefore, activator proteins (e.g., translational activator of cytochrome C oxidase I) either stabilize mtDNA-encoded peptides or interact with translation termination factors to prevent the premature release of the peptides [59].

\section{MPQC: Guardians of the Mitochondrial Proteome}

While living organisms strive to accurately convey genomic information into proteins, errors in protein synthesis and import are inevitable. MPQC, the mitochondrial protein surveillance system, seeks to mitigate these mistakes through multiple mechanisms (Figure 2). In the cytosol, cells utilize the conserved ubiquitin proteasome machineries to target misfolded proteins or those stuck to the OMM for degradation [60]. Inside the mitochondria, chaperones and proteases team up to recognize, refold, and degrade mitochondrial proteins that are disassembled or misfolded [61]. Meanwhile, mitochondrial proteotoxic stress is communicated back to the nucleus, leading to increased transcription of chaperones and proteases. Finally, when beyond repair, the cell sends part of the mitochondrial membrane as secreted vehicles or whole mitochondria to lysosomes for elimination (i.e., mitophagy) [62-64]. All of these MPQC surveillance mechanisms are critical for mitochondrial proteostasis and the overall health of the cell. 


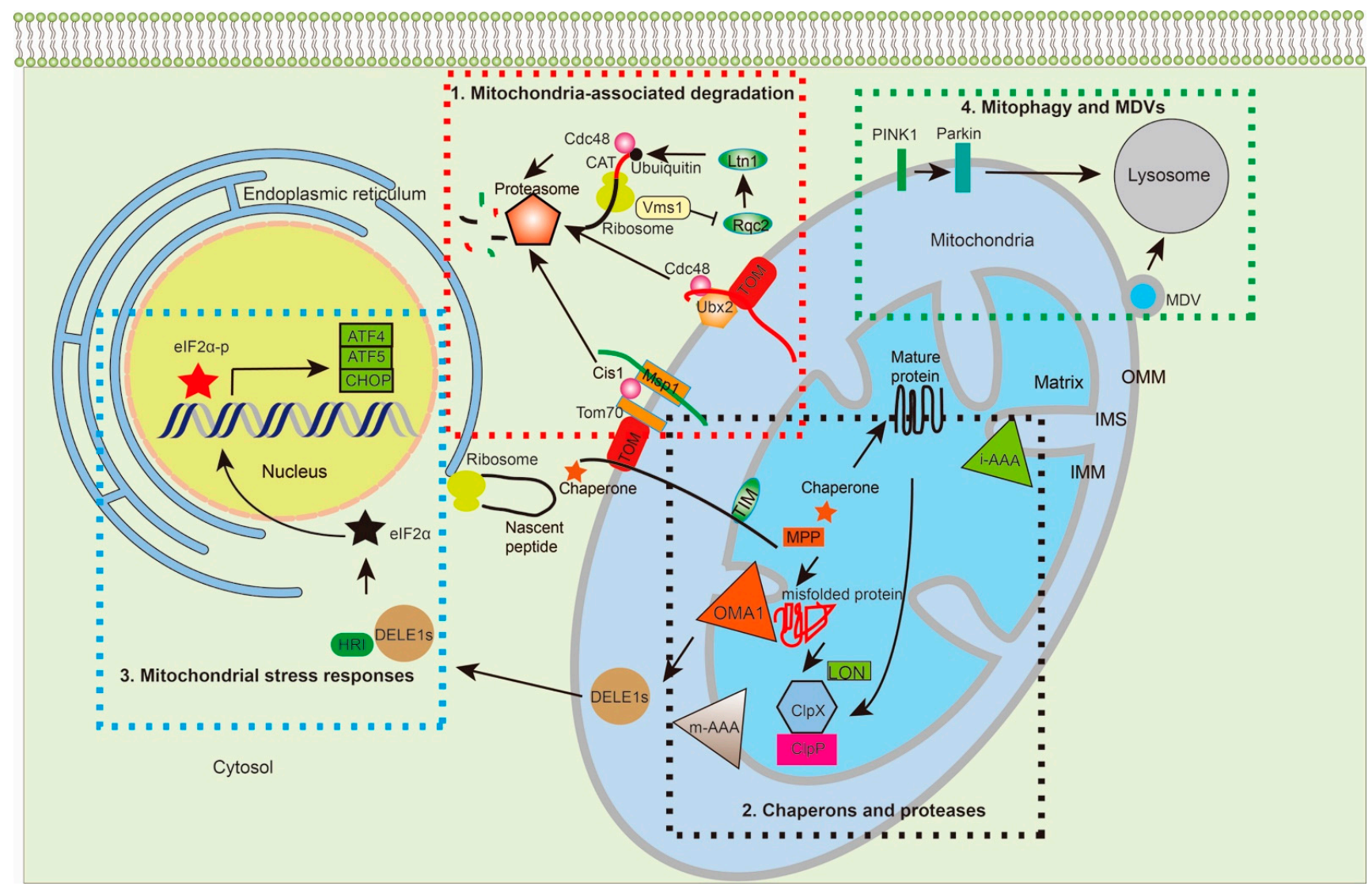

Figure 2. Multiple MPQC pathways surveil protein synthesis, import, folding, assembly, and degradation. The MPQC surveillance system can be divided into four pathways based on studies from yeast and humans: 1. Translocation-associated protein degradation. Under standard culture conditions of yeast, Ubx2 recruits Cdc48 to the TOM complex to target prematurely folded, misfolded, or clogged proteins for proteasome-mediated degradation. Under stress conditions, the cytosolic protein Cis1 links Msp1 to Tom70, enabling Msp1 to extract the target proteins from the TOM complex for degradation. When proteins are stalled at ribosomes, Rqc2 adds CAT-tails to the stalled proteins and facilitates their ubiquitylation by Ltn1. Vms1 removes stalled proteins for degradation through preventing Rqc2 to add CAT-tails. 2. Chaperones and proteases: Chaperones and proteases are important for protein transport, folding, and degradation. Chaperones, such as Hsp70, bind to the newly synthesized proteins and prevent their folding before transporting into mitochondria. Upon transportation into the matrix, MTS is cleaved off by MPP, with mtHsp70 working with Hsp60 to further fold the protein into its functional state. m-AAA and i-AAA are located on the OMM to remove damaged proteins under stress. In the matrix, the proteases, Lon and Plpxp, regulate protein turnover and remove damaged proteins that are accumulated under stress. 3. Mitochondrial stress responses: In humans, the i-AAA protein OMA1 cleaves DELE1 into multiple DELE1s, which interact with HRI to phosphorylate eIF2 $\alpha$. The eIF2 $\alpha$-p further regulates gene expression, such as ATF4, ATF5, and CHOP, the upregulation of which further enables the coping of the stress response. 4. Mitophagy and MDVs: When mitochondrial dysfunction persists and proteostasis cannot be restored, the accumulation of dysfunctional polypeptides together with misfolded and unfolded proteins imposes a severe burden onto mitochondria. Under such conditions, PINK1 phosphorylates Parkin, which ubiquitinates the OMM for mitophagy. MDVs serve as another strategy to remove aberrant mitochondrial proteins without losing the whole organelle. TOM: translocase of the outer membrane; TIM: translocase of the inner membrane; UPS: ubiquitin-proteasome degradation system; MDVs: mitochondria-derived vesicles; PINK1: phosphatase and tensin homolog (PTEN)-induced kinase; Parkin: an E3 ubiquitin-protein ligase encoded by PARK2; i-AAA: inner membrane-embedded AAA protease; m-AAA: matrix-embedded AAA protease; MPP: matrix processing peptidase; OMA1: overlapping activity with m-AAA protease; Lon: Lon protease; Clpx: ATP-dependent Clp protease proteolytic subunit X; Clpp: ATP-dependent Clp protease proteolytic subunit P; Ubx2: UBX domain-containing protein 2; Rqc2: ribosome quality control complex subunit 2; Ltn1: E3 Ubiquitin Ligase Listerin; Cdc48: Cell division control protein 48; Cis1: citrinin sensitive knockout protein 1; ATF4: Activating Transcription Factor 4; ATF5: Activating Transcription Factor 5; CHOP: C/EBP homologous protein. 


\subsection{Mitochondria-Associated Degradation Pathways}

Mitochondrial proteins are primarily synthesized in the cytosol and then transported into their respective compartments where they execute their functions. The normal importing process is illustrated in sections above and in Figure 1. Defects in this process result in the mislocalization of mitochondrial proteins in the cytoplasm or OMM. Despite the efforts of cytosolic chaperones and co-chaperones in preventing protein aggregation, some precursors still become prematurely folded or misfolded, leading to both failure to pass through the TOM complex and a clogged channel on the OMM [31,65]. In yeast, defects in mitochondrial protein import lead to enhanced proteasomal activity and degradation of these precursor proteins in the cytosol $[31,60]$. Specifically, they employ three MPQC pathways: (1) mitochondrial protein translocation-associated degradation (mitoTAD), (2) mitochondrial compromised protein import response (mitoCPR), and (3) mitochondria-localized ribosome-associated quality control (mitoRQC).

\subsubsection{MitoTAD}

MitoTAD serves as an MPQC pathway to clear trapped precursors from the TOM channel under non-stressful, standard growth conditions, using UBX domain-containing protein 2 (Ubx2) as the key regulator. Ubx2 normally functions in the Doa10 and Hrd1 E3 ubiquitin complexes, serving as an adaptor for the Ufd1-Cdc48-Npl4 complex in endoplasmic reticulum-associated degradation [66,67]. On the OMM, Ubx2 binds to Tom40 without interacting with Doa10 and Hrd1, utilizing its UBX domain to recruit the Ufd1-Cdc48-Np14 complex to the TOM complex [65]. The co-factors, Ufd1 and Npl4, facilitate the association of Cdc48 with the TOM complex and work together with Cdc48 to remove clogged precursors for proteasome-mediated degradation under standard growth conditions [65].

\subsubsection{MitoCPR}

Although the mitoTAD pathway can efficiently monitor the TOM complex to prevent clogging of the import channel, this process does not work well under stress conditions. Pathological conditions, such as decreased membrane potential induced by OXPHOS inhibitors or the overexpression of hydrophobic-fragment-containing proteins that are prone to clog the TOM channel, activate mitochondrial precursor overaccumulation stress (mPOS) [68]. Under the mPOS, the target of rapamycin (TOR) signaling is inhibited, leading to reduced import of mitochondrial proteins. Anti-degenerative genes, such as Zinc finger protein Gis2 and Nucleolar GTP-binding protein 2 (Nog2), are upregulated in response to $\mathrm{mPOS}$ to promote cell survival. Mistargeting of mitochondrial proteins can also induce an unfolded protein response activated by mistargeting of proteins (UPRam), leading to the upregulation of certain proteins [69]. For example, the overexpression of mistargeted proteins Pet191 and Mix17 significantly increased proteasomal activity while reducing protein synthesis. Hence, both mPOS and UPRam inhibit protein translation and seek to reduce the proteotoxic stress induced by proteins that fail to import into mitochondria.

When traveling from the cytosol to the OMM, mitochondrial protein precursors are recognized by the channel-forming protein Tom 40 and its three small Tom partners (Figure 1) [70-73]. These three Tom receptors possess partially overlapping specificities and can substitute for each other in recognizing substrates. When one receptor is defective, the other two receptors can facilitate the import of precursor proteins, albeit with reduced efficiency [74]. In yeast, the mitochondrial comprised protein import response (mitoCPR) is activated by proteotoxic stress resulting from unimported proteins. During mitoCPR, the transcription factor heat shock factor 1 (Hsf1) can upregulate the expression of chaperones and proteases to enhance MPQC and reduce proteotoxic stress [75]. In addition, pleiotropic drug resistance protein (Pdr3) is responsible for the transcriptional reprogramming during mitoCPR [76]. For instance, the transcription factor Pdr3 activates expression of the cytosolic protein citrinin sensitive knockout protein 1 (Cis1) [76]. Then, the cytosolic Cis1 recruits AAA ATPase Mitochondrial Sorting of Protein 1 (Msp1) to Tom70 and targets 
stalled proteins from the translocase for proteasome-mediated degradation [76]. Msp1 also extracts mistargeted ER and peroxisomal tail-anchored proteins from the OMM [77-79]. However, whether mitoCPR exists in higher eukaryotes remains unclear.

\subsubsection{MitoRQC}

If faulty proteins become stuck at ribosomes during translation, the RQC removes the stalled protein and promotes its degradation [80]. In yeast, the ribosome quality control complex subunit 2 (Rqc2) and a ubiquitin E3 ligase Ltn1 are the key regulators in preventing the import of faulty polypeptides [81]. Specifically, Rqc2 recruits the E3 ubiquitin ligase listerin (Ltn1) to ubiquitinate the stalled polypeptides on the ribosome. Subsequently, the ubiquitinated peptides are removed from the $60 \mathrm{~S}$ ribosome by Cdc 48 for proteasome-mediated degradation. If lysine residues of the faulty polypeptides are buried in the ribosome and are not available for ubiquitylation, Rqc2 adds alanine and threonine (CAT) tails to the ribosome-stalled polypeptides, enabling the exposure of the buried lysine residues. However, the CAT-tailed nascent chains can form aggregates in the cytosol or mitochondria after being imported. As an alternative mechanism, the peptidyltRNA hydrolyase Vms1 can also dock on the ribosome to release the stalled peptides for proteasome-mediated degradation. Hence, $\mathrm{Vsm} 1$ 's binding to the ribosome can prevent Rqc2 from recruiting Ltn1 and minimize Rqc2's ability to add the CAT tails to the nascent polypeptides $[82,83]$.

\subsection{Chaperones and Proteases: Guarding Proteins Inside Mitochondria}

MPQC inside the matrix is relatively independent from its cytosolic counterpart. It is well equipped with numerous chaperones and proteases to facilitate the proper folding, functional assembly, and correct localization of proteins. When proteins are misfolded or unfolded, proteases inside the mitochondrial matrix cleave them to clear out these faulty proteins.

\subsubsection{Chaperones}

Chaperone proteins represent one major class of enzymes in MPQC [84]. The chaperone families include Hsp40, Hsp60, Hsp70, Hsp90, Hsp100, and sHsp (small Hsp), which are all ATPases and named based on their estimated molecular masses [85]. In this section, we mainly focus on Hsp70, Hsp60, and Hsp90, which are critical players in MPQC.

Prior to and during protein import, precursors need to remain in an unfolded state in order to pass through the small translocase channels, which is facilitated by the highly conserved molecular chaperone Hsp70. Hsp70 binds to the cytosolic precursors via its substrate binding domain until these precursor proteins are captured by the specific protein machineries, which deliver them to the translocation channels on the OMM [86]. After reaching the desired compartment, imported proteins need to be refolded to achieve their functional conformation. mtHsp70 works closely with Hsp60 and other chaperones, such as J-family co-chaperones, to fold the imported proteins and thus prevent their aggregation [87-89]. The coordinated efforts of chaperones and co-chaperones in protein import, folding, and assembly minimize the accumulation of non-functional proteins and ensure the formation of proper protein complexes.

Hsp60 and its co-chaperone Hsp10 form a symmetric double-ring structure and are typically located inside the mitochondria. This protein folding apparatus can interact with and accommodate unfolded polypeptide chains up to $60 \mathrm{kDa}[90,91]$. While Hsp60 binds to the unfolded proteins [92], Hsp10 acts on the outer border of the heptameric ring to open and close the ring, which regulates both the interactions of the Hsp60 monomers and its ATP hydrolysis [93].

Acting downstream of Hsp70, Hsp90 is localized inside the mitochondrial matrix to assist protein folding [94]. In bacteria, TPR domain-containing family Hop uses multiple TPR domains to bind to Hsp70 and Hsp90 simultaneously. Both bacterial Hop and its yeast homolog (i.e., Sti) can promote Hsp90-stimulated refolding in rabbit reticulocyte 
lysate [95]. Interestingly, a recent report indicates that the Hsp70-Hsp90 cascade does not fold proteins directly; instead, it prepares proteins for spontaneous, productive folding. At physiological concentrations, Hsp70 stalls protein folding by binding to their hydrophobic, core-forming segments. However, Hsp90 can break this deadlock and restart the folding process [96]. Regardless, neither Hsp70 nor Hsp90 alters the folding rate despite ensuring high folding yields.

\subsubsection{Proteases}

Another group of enzymes in MPQC is the proteases, which are responsible for the protein turnover and processing. The protein density on the IMM is particularly high, enabling it to appropriately respond to nutrient and oxygen supply. Two hexameric AAA proteases, i-AAA and m-AAA, play a central role in surveilling proteins on the IMM. The name of these two proteases is derived from the fact that the catalytic domain of human m-AAA protease homologs - AFG3-like protein 2 and Paraplegin - faces the matrix while the catalytic domain of the i-AAA protease homolog - ATP-dependent zinc metalloprotease YME1L1, overlapping with the m-AAA protease 1 (OMA1) and mitochondrial inner membrane protease ATP23 homolog - intervenes in the IMS. Both proteases contain an AAA domain, which delivers substrates to their proteolytic center $[97,98]$. These membrane AAA proteases have several important roles, the most important of which is to control the quality of mitochondrial membrane proteins, especially for the respiratory chain proteins on the IMM $[99,100]$. In addition, under stressful conditions, the i-AAA protease YME1L removes the TIM17A protein from the OMM, thus reducing protein import into the mitochondria [101]. YME1L and OMA1 can also cleave Optic atrophy protein 1 (OPA1), generating the short form of OPA1 to regulate mitochondria fission [102]. However, when ATP is depleted under mitochondrial stress and the IMM is depolarized, the ATPindependent protease OMA1 can degrade YME1L, impairing the proteolytic processing of OPA1 [103,104].

In humans, there are two AAA proteases, CLPXP and LON protease (LON, Pim1 in yeast), inside the mitochondrial matrix, which degrade misfolded proteins and prevent protein aggregation $[105,106]$. CLPXP consists of the conserved ATP-dependent Clp protease proteolytic subunit ClpP protease and the chaperone ATP-dependent Clp protease ATP-binding subunit ClpX that functions as an unfoldase and delivers substrates in an ATP-dependent manner to ClpP [107]. In bacteria, chaperones such as ClpA and ClpC function similarly to ClpX to regulate the substrate interaction [108]. The yeast mitochondria lack ClpP and mainly depend on Pim1 for processing misfolded proteins. When misfolded and unfolded proteins in mitochondria trigger the UPR, the expression of ClpP and other chaperones increase accordingly [109].

In bacteria, Lon protease is a well-known proteolytic enzyme with three functional domains: the catalytic protease domain, the ATP-binding domain, and the $\mathrm{N}$-terminal substrate binding domain $[110,111]$. Homologs of the Lon protease are also found in eukaryotes as one of the major enzymes exerting proteolytic activities in mitochondria [112]. For instance, Lon removes the metabolic enzyme aconitase under stressful conditions, which is prone to oxidative stress damage, thus minimizing its accumulation as aberrant protein aggregation in the matrix [113].

\subsection{Mitochondrial Stress Responses}

The main cause of mitochondrial dysfunction is impaired protein transport, which leads to the accumulation of precursors in the cytosol and on the OMM. The proteotoxic stress will trigger the previously mentioned mitochondrial protein import-associated degradation pathways, such as mitoTAD and mitoCPR. Meanwhile, the proteotoxic stress induced by these non-imported precursor proteins can activate the mitochondrial unfolded protein response $\left(\mathrm{UPR}^{\mathrm{mt}}\right)$, which subsequently upregulates the expression of genes encoding mitochondrial chaperones and proteases [31]. In C. elegans, the UPR ${ }^{\mathrm{mt}}$ is regulated by transcription factor stress activated transcription factor Atfs-1, the activating transcription 
factor 5 (ATF5) in mammalian cells, which contains both an MTS and a nuclear localization sequence (NLS) [114]. Under normal conditions, Atfs-1 is imported into the mitochondrial matrix and degraded by the protease Lon. Under conditions of mitochondria dysfunction, Atfs-1 import is reduced with protein accumulation in the cytosol. Atfs-1 utilizes its NLS to travel to the nucleus, activating downstream transcription [115]. Specifically, Atfs-1 induces the expression of genes encoding $\mathrm{UPR}^{\mathrm{mt}}$-relevant proteins, such as the mitochondrial chaperone $\mathrm{Hsp} 60$ and the protease $\mathrm{ClpP}$, as well as over 500 genes that impact diverse cellular activities including mitochondrial protein homeostasis, protein import, innate immunity, and mitochondrial metabolism [115-117].

In humans, ATF5, the ortholog of Atfs-1, regulates gene expression in the UPR ${ }^{\mathrm{mt}}$. ATF5, with two other transcription factors ATF4 and CHOP, are involved in the integrated stress response (ISR), which is a general stress response pathway that modulates protein biosynthesis [118]. Four ISR kinases have been discovered to phosphorylate eukaryotic initiation factor $2 \alpha$ (eIF2 $\alpha$ ), including general control non-depressible 2 (GCN2), hemeregulated inhibitor (HRI), PKR-like endoplasmic reticulum kinase (PERK), and protein kinase R (PKR) [119]. The phosphorylated eIF2 $\alpha$ further results in the suppression of global protein synthesis, while increasing the translation of mRNA with small upstream open reading frames in the $5^{\prime}$ untranslated region, including ATF4, ATF5, and CHOP [120-122].

Despite the above findings, how mitochondrial stress is linked to this general stress response pathway is not entirely clear. Recent studies show that mitochondrial dysfunction activates the inner membrane protease OMA1, which then cleaves DAP3-binding cell death enhancer 1 (DELE1), which is a protein localized in the IMS. This cleaved fragment (DELE1s) is exported into the cytosol, where it interacts with HRI and induces the phosphorylation of eIF $2 \alpha$ and subsequent changes described above [123-125].

\subsection{Mitophagy and Mitochondria-Derived Vesicles (MDVs)}

If the mitochondrial dysfunction persists and proteostasis cannot be restored by the strategies mentioned above, these dysfunctional polypeptides and proteins impose a heavy burden to mitochondria. Under such circumstances, cells initiate mitophagy to eliminate the damaged mitochondria [126]. In mammalian cells, the mitophagy pathway involves two proteins: PTEN-induced kinase 1 (PINK1) and the E3 ubiquitin ligase Parkin. In healthy mitochondria, PINK1 is imported via the TOM and TIM23 complexes into the IMM where the proteases, presenilins-associated rhomboid-like protein and MPP, remove the MTS of PINK1 $[127,128]$. Subsequently, it is translocated back into the cytosol and degraded by the proteasome. When mitochondria are damaged (e.g., through reduction of the membrane potential), PINK1 remains at the OMM bound to the TOM complex and exposes its catalytic domain toward the cytosol. Then, it phosphorylates the E3 ubiquitin ligase Parkin and ubiquitin on the OMM. Parkin is activated on the mitochondrial surface and subsequently ubiquitylates different outer membrane proteins to label the damaged mitochondria for mitophagy [126,129].

If cells cannot afford the loss of mitochondria, they will adopt an alternative mechanism, MDVs, to remove aberrant mitochondrial proteins $[126,130]$. The formation of MDVs, with a size ranging from 70 to $150 \mathrm{~nm}$, is independent from the mitochondrial fission machinery. Through MDVs, the cell transports a distinct subset of mitochondrial proteins to peroxisomes or late endosomes/lysosomes for degradation [131]. However, the regulatory events associated with the generation of the MDVs and involvement of the MDVs in pathophysiology is not well-established and therefore requires further studies.

\section{MPQC Goes Awry in Cancer}

Despite their efforts to maintain mitochondrial proteostasis, cancer cells with genetic mutations or altered expression of MPQC components will unfortunately show compromised MPQC, leading to proteotoxicity and dysfunctional mitochondria. Early in 1920, Otto Warburg had already proposed that cancer cells are defective in mitochondrial respiration [132-134]. On the other hand, somatic mutations or altered expression of MPQC 
components in many cancer cells arise either directly or indirectly from abnormal mitochondrial respiration $[132,135]$. Based on their effects on tumorigenesis, these altered genes are categorized as oncogenes or tumor suppressors (Table 1). Oncogenes are those that promote tumor cell proliferation, immune evasion, genomic instability, and/or cancer invasiveness [136]. Since the inactivation of oncogenes often reduces tumor progression, they represent promising therapeutic targets for cancer treatment. In contrast, tumor suppressor genes tend to be downregulated during malignant transformation and progression, and their upregulation, in theory, would kill cancer cells [137]. Finally, some genes can also have dual effects in promoting or suppressing tumor depending on the specific context of the cancer.

Table 1. MPQC players involved in tumorigenesis.

\begin{tabular}{|c|c|c|c|c|c|c|}
\hline Genes & $\begin{array}{c}\text { Genetic } \\
\text { Alterations }\end{array}$ & $\begin{array}{l}\text { Effects on } \\
\text { Tumor }\end{array}$ & Cancer Context & Mechanisms of Action & Targetability & References \\
\hline MRPS16 & Overexpression & Promoting & Glioma & $\begin{array}{l}\text { Promotes glioma cell } \\
\text { growth, migration, and } \\
\text { invasion by the activating } \\
\text { the PI3K/AKT/Snail axis }\end{array}$ & Potential & {$[138,139]$} \\
\hline MRPS22 & Overexpression & Promoting & $\begin{array}{l}\text { Non-small cell lung } \\
\text { cancer, breast cancer }\end{array}$ & Facilitates protein synthesis & ND* & {$[140,141]$} \\
\hline $\begin{array}{l}\text { mtHSP70/ } \\
\text { Mortalin }\end{array}$ & Overexpression & Promoting & $\begin{array}{l}\text { Breast cancer, ovarian } \\
\text { cancer }\end{array}$ & $\begin{array}{l}\text { Inactivation of p53 and } \\
\text { deregulation of apoptosis }\end{array}$ & Yes & [21] \\
\hline MEP & Overexpression & Promoting & $\begin{array}{l}\text { Acute myeloid } \\
\text { leukemia } \\
\text { (AML) }\end{array}$ & $\begin{array}{l}\text { Interacts with LETM1 } \\
\text { (respiratory super complex } \\
\text { regulator), a possible } \\
\text { inhibitor of cancer }\end{array}$ & Potential & {$[142,143]$} \\
\hline HSP70 & Overexpression & Promoting & $\begin{array}{l}\text { Breast, endometrial, } \\
\text { gastric, leukemia, } \\
\text { hepatocellular } \\
\text { carcinoma, prostate, } \\
\text { colorectal, lung, } \\
\text { ovarian, melanoma }\end{array}$ & $\begin{array}{l}\text { Cytosolic protein quality } \\
\text { control, apoptosis }\end{array}$ & Yes & [144-149] \\
\hline $\begin{array}{l}\text { MIA40/ } \\
\text { CHCHD4 }\end{array}$ & Overexpression & Promoting & $\begin{array}{l}\text { Glioma, } \\
\text { osteosarcoma, breast, } \\
\text { colon, renal cancer }\end{array}$ & $\begin{array}{l}\text { Oxidoreductase, interacts } \\
\text { with p53, and correlates } \\
\text { with hypoxic gene } \\
\text { regulation that promotes } \\
\text { tumorigenesis }\end{array}$ & ND & {$[26,150,151]$} \\
\hline HSP90 & Overexpression & Promoting & $\begin{array}{c}\text { Hepatocellular } \\
\text { carcinoma, squamous } \\
\text { cell carcinoma, breast } \\
\text { cancer, leukemia, } \\
\text { glioblastoma, lung } \\
\text { adenocarcinoma }\end{array}$ & $\begin{array}{l}\text { Cytosolic protein quality } \\
\text { control, apoptosis }\end{array}$ & Yes & {$[24,152-155]$} \\
\hline POLG1 & $\begin{array}{l}\text { Overexpression } \\
\text { and mutations }\end{array}$ & Promoting & $\begin{array}{l}\text { Breast, pancreatic } \\
\text { cancer, melanoma, } \\
\text { colorectal cancer, } \\
\text { renal carcinoma }\end{array}$ & $\begin{array}{l}\text { Replicates and repairs } \\
\text { mtDNA }\end{array}$ & Yes & [156-158] \\
\hline ICT1 & Overexpression & Promoting & $\begin{array}{l}\text { Colorectal cancer, } \\
\text { prostate, breast, lung, } \\
\text { and gastric cancer }\end{array}$ & $\begin{array}{l}\text { Hydrolyzes peptidyl-tRNAs } \\
\text { from stalled mitoribosomes }\end{array}$ & Yes & {$[68,138,159-164]$} \\
\hline TRIT1 & $\begin{array}{l}\text { Mutation (single } \\
\text { nucleotide } \\
\text { polymorphism) }\end{array}$ & Suppressing & $\begin{array}{c}\text { Lymph node } \\
\text { metastasis in gastric } \\
\text { cancer, lung cancer }\end{array}$ & tRNA binding to ribosome & No & [165-167] \\
\hline LARS2 & Downregulation & Suppressing & $\begin{array}{c}\text { Primary } \\
\text { nasopharyngeal } \\
\text { carcinoma }\end{array}$ & $\begin{array}{l}\text { Protein synthesis, catalyzes } \\
\text { charged leucine tRNA }\end{array}$ & ND & [168] \\
\hline TOM70 & $\begin{array}{l}\text { Altered } \\
\text { interaction }\end{array}$ & Suppressing & Breast cancer & $\begin{array}{l}\text { Interaction with RL2 may } \\
\text { lead to cell death in breast } \\
\text { cancer cells, cytosolic } \\
\text { protein import quality } \\
\end{array}$ & Potential & [169] \\
\hline TOM5 & $\begin{array}{l}\text { Altered } \\
\text { interaction }\end{array}$ & Suppressing & $\begin{array}{l}\text { Non-small cell lung } \\
\text { cancer }\end{array}$ & $\begin{array}{l}\text { Interaction with p53 is } \\
\text { suggested to inhibit cancer } \\
\text { cell proliferation and } \\
\text { stability of TOM }\end{array}$ & Potential & [170] \\
\hline
\end{tabular}


Table 1. Cont.

\begin{tabular}{|c|c|c|c|c|c|c|}
\hline Genes & $\begin{array}{c}\text { Genetic } \\
\text { Alterations }\end{array}$ & $\begin{array}{l}\text { Effects on } \\
\text { Tumor }\end{array}$ & Cancer Context & Mechanisms of Action & Targetability & References \\
\hline PARK2 & Mutations & Suppressing & $\begin{array}{c}\text { Glioblastomas, } \\
\text { neuroblastomas, lung, } \\
\text { breast, and ovarian } \\
\text { cancer }\end{array}$ & $\begin{array}{l}\text { Ubiquitination, mitophagy, } \\
\text { MDVs }\end{array}$ & Yes & [171-173] \\
\hline OMA1 & Downregulated & Suppressing & $\begin{array}{l}\text { Breast cancer, possibly } \\
\text { others OPA1-relevant } \\
\text { cancers }\end{array}$ & $\begin{array}{l}\text { Cleaves proteins such as } \\
\text { OPA1, associated with } \\
\text { apoptotic pathway }\end{array}$ & Potential & [174] \\
\hline$\angle A C T B$ & Downregulated & Suppressing & $\begin{array}{l}\text { Breast cancer, } \\
\text { colorectal, gliomas, } \\
\text { hepatocellular } \\
\text { carcinomas }\end{array}$ & $\begin{array}{l}\text { Regulates complex I of the } \\
\text { ETC }\end{array}$ & Potential & {$[165,166,175-177]$} \\
\hline ANT1 & Downregulated & Suppressing & $\begin{array}{c}\text { Breast cancer, } \\
\text { rhabdomyosarcoma }\end{array}$ & $\begin{array}{l}\text { Catalyzes exchange of } \\
\text { mitochondrial ATP for } \\
\text { cytosolic ADP }\end{array}$ & Yes & [178-180] \\
\hline PITRM1 & $\mathrm{N} / \mathrm{D}$ & Suppressing & $\begin{array}{l}\text { Breast cancer, kidney } \\
\text { renal clear cell } \\
\text { carcinoma, lung } \\
\text { adenocarcinoma } \\
\end{array}$ & $\begin{array}{l}\text { Regulates Kruppel-like } \\
\text { factor } 6 \text { gene, which is a } \\
\text { tumor suppressor }\end{array}$ & ND & {$[167,181]$} \\
\hline $\begin{array}{l}\text { HTRA2 or } \\
\text { OMI }\end{array}$ & $\begin{array}{l}\text { Upregulation } \\
\text { Downregulation }\end{array}$ & $\begin{array}{l}\text { Promoting } \\
\text { Suppressing }\end{array}$ & $\begin{array}{l}\text { Stomach cancer, } \\
\text { thyroid cancer, } \\
\text { hepatocellular } \\
\text { carcinoma } \\
\text { AML } \\
\end{array}$ & $\begin{array}{l}\text { A serine protease in the IMS, } \\
\text { interacts with PHB to } \\
\text { impact cell proliferation, } \\
\text { apoptosis, and } \\
\text { mitochondrial proteostasis }\end{array}$ & Yes & {$[182,183]$} \\
\hline HSP40 & $\begin{array}{l}\text { Upregulation } \\
\text { Downregulation }\end{array}$ & $\begin{array}{l}\text { Promoting } \\
\text { Suppressing }\end{array}$ & $\begin{array}{c}\text { Breast cancer, CRC, } \\
\text { gastric cancer, lung } \\
\text { cancer } \\
\text { Breast cancer, lung } \\
\text { cancer, esophageal } \\
\text { squamous cell } \\
\text { carcinoma } \\
\end{array}$ & $\begin{array}{l}\text { Helps transport proteins } \\
\text { from cytosol to } \\
\text { mitochondria }\end{array}$ & Yes & {$[27,184-189]$} \\
\hline HSP60 & $\begin{array}{l}\text { Upregulation } \\
\text { Downregulation }\end{array}$ & $\begin{array}{l}\text { Promoting } \\
\text { Suppressing }\end{array}$ & $\begin{array}{c}\text { Leukemia, breast, } \\
\text { lung, liver, } \\
\text { glioblastomas, } \\
\text { prostate, ovarian, } \\
\text { neuroblastoma, } \\
\text { neuroblastomas, } \\
\text { cervical, head and } \\
\text { neck, colorectal, } \\
\text { adrenocortical, } \\
\text { pancreatic, } \\
\text { hepatocellular } \\
\text { carcinoma, pancreatic } \\
\text { ductal } \\
\text { adenocarcinoma } \\
\text { Clear cell renal cell } \\
\text { carcinoma }\end{array}$ & $\begin{array}{l}\text { Forms pro-survival } \\
\text { complexes in cancers, } \\
\text { stabilizes proteins in the } \\
\text { matrix }\end{array}$ & Yes & {$[89,190-197]$} \\
\hline PHB & $\begin{array}{l}\text { Upregulation } \\
\text { Downregulation }\end{array}$ & $\begin{array}{l}\text { Promoting } \\
\text { Suppressing }\end{array}$ & $\begin{array}{l}\text { Breast cancer, gall } \\
\text { bladder, ovarian } \\
\text { cancers } \\
\text { Gliomas, } \\
\text { nasopharyngeal, and } \\
\text { hepatocellular } \\
\text { carcinomas, both in } \\
\text { gastric cancers }\end{array}$ & $\begin{array}{l}\text { Cell cycle regulation, } \\
\text { apoptosis, mitochondrial } \\
\text { stability }\end{array}$ & ND & [198-201] \\
\hline RMND1 & $\begin{array}{l}\text { Upregulation } \\
\text { Downregulation }\end{array}$ & $\begin{array}{l}\text { Promoting } \\
\text { Suppressing }\end{array}$ & $\begin{array}{l}\text { Breast cancer, chronic } \\
\text { myeloid leukemia } \\
\text { Breast cancer }\end{array}$ & Assembly of mitoribosome & ND & {$[178,179,202]$} \\
\hline$C L P P$ & $\begin{array}{l}\text { Upregulation } \\
\text { Downregulation }\end{array}$ & $\begin{array}{l}\text { Promoting } \\
\text { Suppressing }\end{array}$ & $\begin{array}{c}\text { AML, breast cancer } \\
\text { Gastric } \\
\text { adenocarcinoma }\end{array}$ & $\begin{array}{l}\text { Degrades damaged or } \\
\text { misfolded proteins }\end{array}$ & Yes & [203-207] \\
\hline
\end{tabular}


Table 1. Cont.

\begin{tabular}{ccccccc}
\hline Genes & $\begin{array}{c}\text { Genetic } \\
\text { Alterations }\end{array}$ & $\begin{array}{c}\text { Effects on } \\
\text { Tumor }\end{array}$ & Cancer Context & Mechanisms of Action & Targetability & References \\
\hline UQCRC1 & $\begin{array}{c}\text { Breast cancer, ovarian } \\
\text { cancer, pancreatic } \\
\text { ductal } \\
\text { Downregulation }\end{array}$ & $\begin{array}{c}\text { Promoting } \\
\text { Suppressing } \\
\text { osteosarcinoma } \\
\text { CRC, clear cell renal } \\
\text { cell carcinomas, } \\
\text { gastric cancer }\end{array}$ & $\begin{array}{c}\text { Cleaves precursors that } \\
\text { enter mitochondria and key } \\
\text { ETC subunits }\end{array}$ & ND & [208-210] \\
\hline UQCRC2 & $\begin{array}{c}\text { CRC } \\
\text { Downregulation }\end{array}$ & $\begin{array}{c}\text { Promoting } \\
\text { Suppressing }\end{array}$ & $\begin{array}{c}\text { Cleaves precursors that } \\
\text { Gliomas }\end{array}$ & $\begin{array}{c}\text { enter mitochondria and key } \\
\text { ETC subunits }\end{array}$ & ND & [211,212] \\
\hline
\end{tabular}

${ }^{*}$ ND, Not done.

\subsection{MPQC-Associated Genes as Oncogenes}

Among the regulators involved in the MPQC pathways, gain-of-function mutations or the enhanced expression of certain genes, such as chaperones and enzymes involved in mitochondrial transcription and translation, can promote tumorigenesis. Several of them are summarized as examples below, with the rest listed in Table 1.

\subsubsection{Genes Encoding Mitochondrial Chaperones}

In addition to their role in facilitating protein import into mitochondria, several chaperones and co-chaperones are also linked with tumorigenesis. For example, HSP70 is an ATP-dependent molecular chaperone that transfers precursors from cytosolic ribosomes to the OMM (Figure 1). Similar to other heat shock proteins, HSP70 levels are elevated under cellular stress to enable cells coping with the accumulation of unfolded or denatured proteins [213]. The overexpression of HSP70 was shown to promote the survival of malignant cells [214]. HSP70 can stabilize serine threonine kinase AKT/PKB through their physical interaction, which generates a survival signal in response to the stimulation of growth factors. In addition, Hsp70 can bind to stress-activated kinases, including apoptosis signal regulating kinase 1 (ASK1), c-Jun N-terminal Kinase JSK, and P38 kinase, to inhibit their functions. At the mitochondrial level, the concerted action of HSP70 and HSP40 blocks the translocation of BAX from mitochondria to cytosol, thus inhibiting apoptosis [215]. At the post-mitochondrial level, HSP70 binds to apoptosis protease activating factor 1 to prevent the recruitment of procaspase- 9 to the apoptosome [216]. Furthermore, together with HSP40, HSP70 inhibits tumor necrosis factor- $\alpha$ (TNF- $\alpha$ )-induced neuronal cell death by interacting with Fanconi anemia complementation group $\mathrm{C}$, which inhibits interferon-inducible dsRNA-dependent protein kinase, a proapoptotic protein [217]. Furthermore, HSP70 can also negatively impact the autophagic pathways by activating mTOR, the negative regulator of macroautophagy, and inducing AKT phosphorylation in the lysosomes [218]. Finally, enhanced HSP70 expression can also induce resistance to chemotherapy, such as the tyrosine kinase inhibitor imatinib in human chronic myeloid leukemia cells [219]. HSP70's ability in promoting tumor cell survival and drug resistance makes its neutralizing agents promising therapeutics for leukemia, breast, prostate, gastric, endometrial, and pancreatic cancers [218].

HSP90, another ATP-dependent molecular chaperone, hands precursor proteins to TOM and facilitates the folding, maturation, and activation of a wide array of target proteins (Figure 1) $[220,221]$. Similar to other heat shock proteins, the upregulation of HSP90 and enhancement of its ATPase activity are observed under cellular stress including heat, nutrient absence, and oxidative stress [222,223]. When overexpressed, HSP90 plays a major role in restoring proteostasis, thereby promoting cell survival, including that of cancer cells. HSP90 facilitates the correct folding of nascent peptides and increases the reactivation rates of damaged proteins [224]. In cancerous cells, HSP90 also stabilizes mutant proteins, ranging from those with point mutations to those with structural alterations such as BCR-ABL, thus enabling malignant transformation [225]. 
Mortalin/mtHsp70 is the only component of the TIM23 complex harboring the ATPase activity, which facilitates the transport of nascent peptides through the IMM and their proper folding (Figure 1). Mortalin is essential for mitochondrial biogenesis due to its ability to enable ATP-driven translocation of nascent peptides through binding to the Tim44 subunit (Figure 1) [226]. The expression of mortalin is significantly higher in most cancer cells, including those of breast, ovarian, and colorectal cancer [227]. Mortalin is shown to inactivate the pro-apoptotic role of $\mathrm{p} 53$, which makes its overexpression sufficient to promote cancer development in both in vitro and in vivo models, one type being breast cancer [228].

\subsubsection{Mitochondrial Regulators of Transcription and Translation}

In addition to chaperones and co-chaperones, the transcriptional and translational regulators of mitochondrial proteins can also facilitate tumorigenesis. One regulator is mitochondrial DNA polymerase gamma 1 (POLG1), a catalytic subunit of POLG, which is the only DNA polymerase known to function in human mitochondria. The normal role of POLG1 is to replicate and repair mtDNA in the matrix, serving as an essential regulator for mtDNA and general mitochondrial function. Mutations and the overexpression of POLG1 are commonly observed in melanoma, renal carcinoma, breast, pancreatic, and colorectal cancer (CRC). Some of the common mutations in POLG1 include E1143G, T251L, P587L, and double mutant T251L/P587L [156]. When these mutations were introduced to breast cancer cell lines, they decreased mitochondrial membrane potential and increased reactive oxygen species (ROS) levels and tumor cell invasion [157]. miRNA-array analysis demonstrated a depletion of mtDNA in these POLG1 mutant cells $[157,158]$. Furthermore, POLG1 E1143G cells significantly increased glucose consumption rates, displaying a switch to the aerobic glycolysis signature [156].

The mitochondrial small ribosomal subunit protein BS16m (MRPS16) is in charge of both mt-SSU assembly and nick introduction to supercoiled DNA in the matrix $[229,230]$. The overexpression of MRPS16 is often found in glioma tissues and promotes tumorigenesis in animal models [138]. In an in vitro study, MRPS16 inactivation was found to suppress tumor cell growth, migration, and the invasion of human glioma cells by inhibiting the PI3K/AKT signaling [138]. In addition, MRPS16 depletion also inhibited tumor growth in mice. Thus, MPRS16 represents a promising prognostic marker and potential therapeutic target for glioma [139].

The normal function of immature colon carcinoma transcript 1 (ICT1), a matrix protein, is to induce the hydrolysis of peptidyl tRNAs from stalled mitoribosomes [159]. In 1995, the abnormal expression of ICT1 was first found in CRC and identified as a regulator of cell differentiation [138]. High ICT1 expression in tumor tissues predicts worse overall survival in CRC patients. ICT1 knockdown by shRNA suppressed proliferation and colony formation while inducing apoptosis in multiple types of cancer cells, including those of colorectal, prostate, breast, gastric, and lung cancer [68,160-163]. Western blot analysis showed that the AMPK $\alpha, \mathrm{BAD}, \mathrm{SAPK} / \mathrm{JNK}$, and PARP signaling were altered upon ICT1 knockdown. Furthermore, cell cycle regulators, including CDK1 and cyclin B1, were downregulated, while apoptotic factors, such as cleaved PARP, caspase 3 , and BAX, were upregulated [68,161-163]. Finally, ICT1 is also a direct target of miR-205, which exerts suppressive effects on tumor metastasis [164]. Hence, inhibiting ICT1 by RNAi or small molecular inhibitors could serve as a novel therapeutic approach for a range of cancers [68,160-163].

\subsection{MPQC-Associated Genes as Tumor Suppressors}

While the hyperaction of the above MPQC genes drives tumorigenesis, other MPQC components tend to be downregulated in cancers, which include regulators inside and outside the mitochondria. In this section, we will discuss the mutations of key MPQC proteins and how these alterations impact cancer development as tumor suppressors. 


\subsubsection{MPQC Components Outside the Mitochondria}

Among MPQC regulators, the tRNA isopentyl transferase 1 (TRIT1) resides in the nucleus, cytoplasm, and matrix, working to add an isopentyl group to adenosine 37 on tRNA [231-233]. The addition of the isopentyl group increases the affinity of tRNA for the ribosome. TRIT1 modifies serine tRNA for cytosolic proteins, as well as tryptophan, tyrosine, serine, phenylalanine, and cysteine tRNAs for mitochondrial proteins [234]. Single-nucleotide polymorphisms of TRIT1 are associated with cancer progression, including increased lymph node metastasis in gastric cancers [235]. One variant of TRIT1, TRIT1-F202L, was found to predict poor survival among patients with lung cancer [236]. A mouse study shows that TRIT1 mRNA is downregulated in lung cancer cells, while its overexpression decreases the rates of lung tumor development [237]. Its role as a tumor suppressor is most likely linked with its activities in the nucleus, since its yeast homolog, tRNA dimethylallyltransferase (Mod5), is associated with tRNA transcription complexes and pre-tRNAs [235]. Although how nuclear TRIT1 suppresses human cancer remains unclear, research suggests that TRIT1 binds to tRNA in a similar manner to Mod5 [238].

The Parkin protein resides in the cytosol, serving as an E3-ubiquitin ligase. Upon activation by PINK1, Parkin targets proteins on the OMM for degradation or induces mitophagy when they accumulate [239]. Although mitophagy may exhibit a dual role in tumorigenesis in general, the mitophagy mediated by the PINK1-Parkin pathway exerts tumor suppression in a variety of cancer types [240]. Mutations in PARK2, the gene encoding Parkin, are prevalent in a broad spectrum of cancers, such as melanoma, gliomas, neuroblastomas, breast, lung, and colon cancer [240]. One example is that a restored expression of PARK2 decreases the rate of tumor cell proliferation in gliomas [241]. A crucial tumor suppressive effect of Parkin is likely associated with its regulation of P53 in glucose metabolism and its ability to reverse the Warburg effect $[173,240]$. One of Parkin's substrates is cyclin E, which is a critical regulator for cell cycle progression, and its degradation would lead to cell cycle arrest, thus halting cancer development [241]. Another mechanism by which Parkin suppresses tumor growth is through its ability to inhibit necroptosis, which is a programmed inflammatory cell death. Necroptosis signifies inflammation, which contributes to the development of cancers such as CRC [242]. While Parkin facilitates P53's response to the Warburg effect and antioxidant defenses [173], its ability to ubiquitinate hypoxia-inducible factor $1 \alpha$, a crucial mediator for cancer metastasis, also contributes to tumor suppression [243]. Rotenone, and a combination of mitocans with demonstrated anticancer effects (e.g., metformin), may be effective in targeting the PINK1-Parkin pathway of mitophagy in cancer, such as acute lymphoblastic leukemia (ALL) [244]. Compounds, including derivatives of betulinic acid, have been found to trigger ROS and PINK1-Parkinmediated mitophagy to induce apoptosis in multi-drug-resistant cancer cells [245].

\subsubsection{MPQC Players inside Mitochondria}

Serine B-lactamase-like protein (LACTB), a mitochondrial protease, localizes in the IMS, regulating complex I of the ETC and lipid metabolism within the mitochondria $[165,176]$. LACTB is downregulated in cancer cells through multiple mechanisms, including micro-RNA-mediated translational inhibition, promoter methylation, and histone acetylation $[165,177,246]$. The overexpression of $L A C T B$ negatively impacts the growth of both breast cancer and hepatocellular carcinoma cells by modulating lipid metabolism to promote cancer cell differentiation $[165,166]$. In CRC, the increased expression of LACTB impairs MDM2-mediated p53 ubiquitination and degradation [177]. In gliomas, a downregulation of LACTB leads to an increase in cancer cell proliferation and angiogenesis, corresponding to a poor prognosis in patients, while its overexpression does the opposite by inhibiting PCNA, MMP2, MMP9, and VEGF, which are key regulators in glioma cell proliferation [175].

OMA1, as mentioned above, is a key protease that spans the IMM and contributes to various mitochondrial functions [247,248]. Its substrates include OPA1 (an important regulator for OXPHOS and apoptosis) and PINK1 (a kinase crucial for mitophagy) [248]. Ex- 
cessive OPA1 cleavage by OMA1 leads to mitochondrial fragmentation and cell death [249]. Interestingly, this mechanism could be exploited to effectively kill cancer cells as OPA1 cleavage by OMA1 can induce the release of cytochrome c [250]. Silic-Benussi et al. selectively killed T-ALL cells using compounds that increased ROS levels, thus enhancing the OMA1-OPA1 activity [251]. Targeting the ROS-OMA1-OPA1 axis could serve as a therapeutic strategy and should be investigated further [251]. The cleavage of PINK1 by OMA1 activates protein degradation on the OMM or mitophagy mediated by the PINK1Parkin pathway. A decrease in OMA1 expression correlates with the poor prognosis of patients with breast cancer due to changes in mitochondrial proteostasis and an increase in filopodia-like structures, which promote cell migration and proliferation [174].

Adenine nucleotide translocase 1 (ANT1) resides in the IMM, catalyzing the exchange of mitochondrial ATP for cytosolic ADP. A mouse study shows that the overexpression of ANT1 induces apoptosis and inhibits breast cancer growth by suppressing nuclear factor $\mathrm{KB}(\mathrm{NF}-\mathrm{kB})$, which is a protein critical for DNA transcription and cytokine production [252]. In addition, dysregulated ANT1 is also linked with mitochondrial diseases such as Sengers syndrome and autosomal dominant facioscapulohumeral muscular dystrophy [253]. Recently, restoring ANT1 expression was found to sensitize rhabdomyosarcoma cells to chemotherapy [254], indicating the potential to exploit ANT1 as a target for cancer treatment.

Leucyl-tRNA synthetase 2 (LARS2) resides in the matrix to catalyze the formation of a charged leucine-tRNA, which is essential for mitochondrial translation [255]. The downregulation of LARS2 via promoter hypermethylation or allelic loss correlates to the development of nasopharyngeal carcinoma [168]. In head and neck squamous cell carcinoma, the promoter region of LARS2 is also methylated [256]. The downregulation of LARS2 enhances the proliferation of both types of cancer cells, which is a phenotype consistent with its role as a tumor suppressor, although how it impacts tumor development requires further investigation. Pitrilysin metallopeptidase 1 (PITRM1), another protease in mitochondria, degrades oligopeptides from imported mitochondrial proteins [167]. Although PITRM1 is known to regulate the tumor suppressor Kruppel-like factor 6 gene in breast cancer, kidney renal clear cell carcinoma, and lung adenocarcinoma, further research must be conducted to study its targetability and other implications in cancer [181].

The TOM complex on the OMM could also represent a potential target for cancer treatment as each TOM protein interacts with some of the apoptosis or cancer regulators. For instance, the PINK1-Parkin mitophagy pathway recognizes the TOM complex via the role of PINK1 in detecting accumulated proteins [257]. Another example is that TOM70 is targeted by the myeloid leukemia cell differentiation protein-1, which is an inhibitor of apoptosis and therefore a driver of cancer [258]. TOM5, a protein that helps stabilize the TOM complex, was shown to bind to P53, a well-established tumor suppressor, and their interaction suppresses cancer proliferation in non-small cell lung cancer cell lines [259]. In melanoma cells, TOM20 was found to sense ROS induced by iron and promote pyroptosis, which is a type of cell death [260].

\subsection{Dual Roles of MPQC-Associated Genes in Tumorigenesis}

Among chaperones, proteases, and regulators in the MPQC pathway, many exert distinct roles either as cancer drivers or suppressors. However, in certain cases, some of the MPQC players can have dual roles in tumorigenesis.

\subsubsection{Chaperones}

HSP40 is a cytosolic chaperone, which helps target precursor proteins from the cytosol to the OMM and facilitates protein import, folding, and degradation [24,27]. Various types of HSP40 may impart different effects on cancer cells [184]; for example, two subtypes of DNAJ (the HSP40 family) are implicated in breast cancer development, as the DNAJA subtype induces apoptosis, while the DNAJB subtype inhibits apoptosis [185]. While 
HSP40 has been proposed as a target in cancer, further research is needed to investigate the role of each subtype in various types of cancers [186].

HSP60 is another chaperone protein in MPQC that exhibits a dual role in tumorigenesis. HSP60 resides in the matrix to facilitate the folding and stabilization of precursor proteins that are transported into the mitochondria $[195,261]$. During tumorigenesis, and depending on the cancer context, HSP60 accumulates outside of mitochondria to possibly assist in protein folding and maintain the cell's survival, as in uterine exocervix, prostate, and large bowel cancer cell models [262]. Alternatively, it may exert a pro-apoptotic role by promoting the maturation of procaspase-3, as in JURKAT and HeLa cell lines $[214,217,218]$. HSP60 is overexpressed in a variety of human cancers such as leukemia, neuroblastoma, breast, lung, and liver cancer [185]. The mitochondrial levels of HSP60 in pancreatic ductal adenocarcinomas are positively correlated with disease aggression and cancer cell proliferation through the ability of HSP60 to enhance ERK1/2 phosphorylation and cancer cell survival [197]. Interestingly, in hepatocellular carcinoma (HCC), HSP60 acts as a tumor suppressor by promoting cell differentiation while inhibiting the migration and invasion of HCC cells [196]. In addition, HSP60 was found to interact with HSP10 chaperone and pro-caspase 3 in the matrix of JURKAT T-ALL cells, suggesting its pro-apoptotic activities as a tumor suppressor [193]. HSP60 has already been established as a therapeutic target for treating certain cancers due to its wide upregulation and tumor-driving role [195]. However, little research has been performed to exploit the possibility of overexpressing HSP60 as a means to treat other cancers in which it functions as a tumor suppressor.

Prohibitin (PHB) is a chaperone protein conserved across many species, consisting of two subunits, PHB1 and PHB2, which form a complex in the IMM to stabilize mitochondrial proteins, including OMA1 [263]. While PHB1 is reported to be overexpressed in pancreatic, ovarian, and gallbladder cancer, its downregulation has also been detected in HCC and nasopharyngeal carcinoma [201]. In gastric cancer, PHBs can serve as both oncogenes and tumor suppressors, with either upregulation or downregulation observed in patient tumor samples [199]. As a transcriptional target of MYC, both PHB1 and PHB2 are overexpressed in a variety of cancers, including breast, prostate, colon, testicular, and skin [198]. The tumor-suppressing role of PHB is implicated in its ability to induce p53-mediated transcription and repress E2F-mediated transcriptional activity [264,265]. In addition, PHB can also block cells' entry into the S phase of the cell cycle [199]. In particular, PHB2 can promote mitophagy by stabilizing and helping maintain the PINK1-Parkin pathway [200]. The wide involvement of PHB in cancer necessitates further research to dissect the role of each PHB subunit in specific cancer contexts, in order to devise suitable approaches for therapeutic intervention.

\subsubsection{Proteases and Other MPQC Regulators}

Among the proteases involved in MPQC, the ATP-dependent Clp protease proteolytic subunit (CLPP) is located in the matrix with its normal function to degrade damaged or misfolded proteins [266]. One of the CLPP substrates is succinate dehydrogenase subunit A, which is a part of complex II in the ETC, implicating its role in OXPHOS [203,267]. CLPP is also involved in mitochondrial transcription and translation, since one of its substrates, the mitochondrial GTPase Era 1, can inhibit the activity of the mitoribosome [207]. In terms of its oncogenic role, Cole et al. showed that CLPP is overexpressed in a majority of acute myeloid leukemia (AML), and CLPP inactivation selectively killed AML cells as a result of impaired ETC activity and increased ROS [203]. CLPP is also overexpressed in breast cancer, and CLPP depletion inhibits the SRC/PI3K/AKT pathway, which is crucial for cancer cell proliferation and invasion [206]. Compounds, such as imipridones, were found to hyper-activate CLPP, which in turn led to the death of subsets of AML, cervical, breast, ovarian, and colon cancer cells [204,205]. CLPP's role as a tumor suppressor is not as well understood, with its downregulation detected in gastric adenocarcinomas [268].

As the key subunits of the ETC complex III, the ubiquitin-cytochrome c-reductase complex core proteins 1 and 2 (UQCRC1 and UQCRC2) have been reported to be either 
upregulated or downregulated in various cancers. UQCRC1 and UQCRC2 are homologous to the two subunits of MPP ( $\beta$ and $\alpha$ respectively) and cleave precursors of mitochondrial proteins that are imported into the matrix [269]. UQCRC1 is overexpressed in pancreatic ductal adenocarcinomas, osteosarcomas, as well as in breast and ovarian cancer, while it is downregulated in the clear cell subtype of renal cell carcinomas, CRC, gastric, and breast cancer [208-210]. The overexpression of UQCRC1 increased the growth rates of pancreatic ductal adenocarcinoma cells in vitro and in vivo through activating the eATP/P2Y2RKT/AKT pathway [208]. UQCRC1 downregulation in CRC was found to correlate with lymph node metastasis and poor patient prognoses [210].

The oncogenic role of UQCRC2 is indicated by its overexpression in CRC and human lung adenocarcinomas, as well as its correlation with cancer invasion and metastasis. UQCRC2 also plays a role in inducing ROS, which can promote tumorigenesis, and its knockdown induces the apoptosis of CRC cells [211]. On the other hand, UQCRC2 can inhibit glioma progression as it mediates the effect of cadherin 18 on suppressing the invasion of glioma cells [212]. Despite this knowledge, drugs that specifically target UQCRC1 and UQCRC2 have not yet been developed.

The required-for meiotic nuclear division 1 homolog (RMND1) localizes in the matrix of the mitochondria and organizes the assembly of the mitochondrial ribosome [179,202]. RMND1 is a potential tumor suppressor, as it is downregulated in chronic myeloid leukemia [202]. In the estrogen receptor negative subtype of breast cancer, RMND1 expression is reduced in tumor samples associated with minor risk alleles but increased in those with major risk alleles, suggesting its possible dual role in breast cancer pathogenesis [178]. Regardless, further research is required in order to establish RMND1 as a therapeutic target for cancer treatment.

\section{Therapeutic Exploitation of MPQC for Cancer Treatment}

With the ongoing research on MPQC and its involvement in cancer, a number of drugs and compounds targeting MPQC players have been developed and evaluated for their anticancer effects. In this section, we categorize these drugs and synthetic compounds based on their respective targets (Table 2). Importantly, some of these drugs require the attachment of a mitochondrial targeting compound to help guide them through the mitochondrial membranes and to their target proteins. Finally, we briefly discuss some questions that have arisen from the actionable mechanisms of these drugs and compounds and the possible future directions. Drugs targeting mitophagy include LCL-461, liensinine, chloroquine, and hydroxychloroquine [270].

Table 2. Compounds targeting MPQC players in cancer.

\begin{tabular}{|c|c|c|c|c|c|c|}
\hline $\begin{array}{c}\text { Type of } \\
\text { Compounds }\end{array}$ & Drug Name & Target & Mechanisms of Action & Cancer Types & $\begin{array}{l}\text { Stage of Drug } \\
\text { Development }\end{array}$ & References \\
\hline \multirow{4}{*}{$\begin{array}{l}\text { Inhibitors of } \\
\text { cytosolic } \\
\text { chaperones }\end{array}$} & DMAG & HSP90 & $\begin{array}{l}\text { Inhibits HSP90 by competing } \\
\text { for ATP binding site and } \\
\text { prevents chaperone role }\end{array}$ & $\begin{array}{c}\text { Leukemia, melanoma, } \\
\text { breast and ovarian cancers, } \\
\text { medulloblastoma, cervical } \\
\text { cancer, multiple myeloma, } \\
\text { lung cancer }\end{array}$ & $\begin{array}{l}\text { Clinical trials } \\
\text { completed }\end{array}$ & {$[271,272]$} \\
\hline & PES & HSP70 & $\begin{array}{l}\text { Inhibits HSP70 by acting on } \\
\text { its } C \text { terminal binding } \\
\text { domain, prevents substrate } \\
\text { binding, and induces ROS }\end{array}$ & Lymphoma & $\begin{array}{l}\text { Preclinic } \\
\text { studies }\end{array}$ & {$[273,274]$} \\
\hline & Gamitrinibs & HSP90 & $\begin{array}{l}\text { Binds HSP90 that } \\
\text { accumulates at mitochondria } \\
\text { and allows for cytochrome c } \\
\text { release }\end{array}$ & Prostate & Completed & [275] \\
\hline & Nab-paclitaxel & Microtubules & $\begin{array}{l}\text { Binds to and stabilizes } \\
\text { microtubules, preventing } \\
\text { their depolymerization thus } \\
\text { inhibiting cellular motility, } \\
\text { mitosis, and replication }\end{array}$ & $\begin{array}{l}\text { Non-small lung cell } \\
\text { carcinoma }\end{array}$ & $\begin{array}{l}\text { Active, not } \\
\text { recruiting, } \\
\text { phase } 2\end{array}$ & [276] \\
\hline
\end{tabular}


Table 2. Cont.

\begin{tabular}{|c|c|c|c|c|c|c|}
\hline $\begin{array}{c}\text { Type of } \\
\text { Compounds }\end{array}$ & Drug Name & Target & Mechanisms of Action & Cancer Types & $\begin{array}{l}\text { Stage of Drug } \\
\text { Development }\end{array}$ & References \\
\hline \multirow{4}{*}{$\begin{array}{l}\text { Inhibitors of } \\
\text { mitochondrial } \\
\text { proteins }\end{array}$} & Carboplatin & HSP40, DNA & $\begin{array}{l}\text { Possible connection with } \\
\text { HSP40; used in combinations } \\
\text { with other drugs; induces } \\
\text { intra-strand and inter-strand } \\
\text { DNA cross-links, as well as } \\
\text { DNA-protein cross-links. } \\
\text { These carboplatin-induced } \\
\text { DNA and protein effects } \\
\text { result in apoptosis and cell } \\
\text { growth inhibition }\end{array}$ & $\begin{array}{l}\text { Non-small lung cell } \\
\text { carcinoma, esophageal } \\
\text { adenocarcinoma }\end{array}$ & $\begin{array}{l}\text { Active, not } \\
\text { recruiting, } \\
\text { phase } 2\end{array}$ & $\begin{array}{c}{[277-281]} \\
\text { NCT02716038; } \\
\text { NCT02998268 }\end{array}$ \\
\hline & $\begin{array}{l}\text { ONC201/ } \\
\text { ONC212 } \\
\text { (derivative of } \\
\text { ONC201) }\end{array}$ & CLPP & $\begin{array}{l}\text { Hyperactivates CLPP, which } \\
\text { leads to protein synthesis } \\
\text { inhibition and growth } \\
\text { inhibition, or apoptosis via } \\
\text { tumor-necrosis-factor-alpha- } \\
\text { related apoptosis } \\
\text { ligand }\end{array}$ & $\begin{array}{l}\text { AML, gliomas, cervical, } \\
\text { breast, endometrial, } \\
\text { myeloma, lymphoma, } \\
\text { endocrine, solid tumors }\end{array}$ & $\begin{array}{l}\text { Completed } \\
\text { (solid tumors), } \\
\text { ongoing } \\
\text { testing in } \\
\text { phase } 1 \text { to } \\
\text { phase } 3\end{array}$ & {$[204,282]$} \\
\hline & $\begin{array}{l}\text { AppCCl2P } \\
\text { (metabolite of } \\
\text { clodronate) }\end{array}$ & ANT & $\begin{array}{l}\text { Inhibits ANT (adenine } \\
\text { nucleotide transporter), } \\
\text { mitochondrial oxygen } \\
\text { consumption, and } \\
\text { depolarizes mitochondrial } \\
\text { membrane, all leading to } \\
\text { apoptosis }\end{array}$ & $\begin{array}{l}\text { Breast, bone, prostate, } \\
\text { neoplasm }\end{array}$ & $\begin{array}{l}\text { Phase 3, } \\
\text { completed }\end{array}$ & [283-285] \\
\hline & Chlorambucil & mtDNA & $\begin{array}{l}\text { Chlorambucil with cisplatin } \\
\text { attacks cisplatin-resistant } \\
\text { cancer cells, alkylates } \\
\text { mtDNA, induces apoptosis } \\
\text { through mtDNA damage and } \\
\text { mitochondrial metabolic } \\
\text { pathways by reducing } \\
\text { dependency on glucose, } \\
\text { depolarizes mitochondrial } \\
\text { membrane, and mtDNA } \\
\text { alkylation-induced ROS }\end{array}$ & Prostate, breast & Completed & [286-288] \\
\hline $\begin{array}{l}\text { Targeting } \\
\text { mitophagy }\end{array}$ & $\begin{array}{l}\text { LCL-461, } \\
\text { liensinine, } \\
\text { chloroquine, and } \\
\text { hydroxychloro- } \\
\text { quine, } \\
\text { mito-metformin, } \\
\text { mito-carboxyl- } \\
\text { proxyl-nitroxide }\end{array}$ & & $\begin{array}{c}\text { Prevents fusion of } \\
\text { autophagosomes with } \\
\text { lysosomes and incurs } \\
\text { damage to promote apoptosis }\end{array}$ & $\begin{array}{c}\text { Glioma, multiple myeloma, } \\
\text { melanoma, lung, } \\
\text { pancreatic cancer, sarcoma }\end{array}$ & Completed & {$[270,289]$} \\
\hline \multirow{4}{*}{$\begin{array}{l}\text { Mitochondria- } \\
\text { targeting } \\
\text { molecules }\end{array}$} & Derivatives of TPP & $\mathrm{N} / \mathrm{A}^{*}$ & $\begin{array}{l}\text { Functions as a mitochondrial } \\
\text { targeting signal }\end{array}$ & $\mathrm{N} / \mathrm{A}$ & $\mathrm{N} / \mathrm{A}$ & [277] \\
\hline & $\begin{array}{l}\text { Szeto-Schiller } \\
\text { peptides- } \\
\text { dimethyltyrosine }\end{array}$ & $\mathrm{N} / \mathrm{A}$ & $\begin{array}{c}\text { Targets molecules to IMM } \\
\text { and reduces ROS via its } \\
\text { residues }\end{array}$ & $\mathrm{N} / \mathrm{A}$ & $\mathrm{N} / \mathrm{A}$ & {$[281,283,290]$} \\
\hline & $\begin{array}{l}\text { Pyridinium- } \\
\text { substituted } \\
\text { tetraphenylethy- } \\
\text { lene }\end{array}$ & $\mathrm{N} / \mathrm{A}$ & $\begin{array}{c}\text { Targets IMM, increases ROS, } \\
\text { and disrupts membrane } \\
\text { potential }\end{array}$ & $\mathrm{N} / \mathrm{A}$ & $\mathrm{N} / \mathrm{A}$ & [286-288] \\
\hline & $\begin{array}{l}\text { Indolinium-based } \\
\text { compounds }\end{array}$ & $\mathrm{N} / \mathrm{A}$ & $\begin{array}{c}\text { Increases ROS and } \\
\text { depolarizes membrane } \\
\text { potential }\end{array}$ & $\mathrm{N} / \mathrm{A}$ & $\mathrm{N} / \mathrm{A}$ & {$[289,291]$} \\
\hline
\end{tabular}

${ }^{*} \mathrm{~N} / \mathrm{A}$, not applicable.

\subsection{Targeting Cytosolic Chaperones for Protein Transport}

2-Phenylethynesulfonamide (PES) can inhibit HSP70 by acting on its C-terminal binding domain, which disrupts its substrate binding as well as its interactions with cochaperones $[273,291]$. Although PES can inhibit the transport of P53 to mitochondria and thus block P53-mediated apoptosis, its effect on HSP70 induces an aggregation of misfolded and nascent proteins, leading to tumor cell death [273,291]. PES is also shown to induce apoptosis via ROS in vivo, and clinical trials of this compound could begin soon [274,292]. Although MKT-077, another HSP70 inhibitor, has been terminated in clinical trials due to its toxicity [293], investigations into its derivatives are ongoing [294,295].

One of the HSP90 inhibitor is 17-dimethylaminoethylamino-17-demethoxygeldana mycin (17-DMAG), which is a derivative of the toxic drug, geldanamycin [272]. 17-DMAG, also known as alvespimycin, has shown promising results in preclinical and clinical studies 
for treating a broad spectrum of cancers, such as leukemia, melanoma, medulloblastoma, multiple myeloma, breast, ovarian, cervical, and lung cancer [271,272]. 17-DMAG competes with ATP's binding to HSP90 and thus inhibits its chaperone function [296]. The inhibition of HSP90 by this compound leads to misfolding, ubiquitylation, and degradation of its target proteins [297,298]. Gamitrinibs are a class of mitochondrial matrix inhibitors that targets HSP90 [299]. In cancerous cells, HSP90 accumulates in mitochondria and blocks the release of cytochrome c. Hence, the binding of gamitrinibs to HSP90 unleashes cytochrome $\mathrm{c}$ and the apoptotic pathway. Gamitrinibs are largely studied in prostate cancer and show strong anti-cancer effects [300]. When combined with other anti-cancer drugs, such as doxorubicin, gamitrinibs exhibit strong anti-cancer activity in HeLa cells, ovary, prostate, glioblastoma, renal cell carcinoma, hepatocellular carcinoma, and lung carcinoma cells [275].

Paclitaxel, also known as Taxol as an anti-microtubule agent, exerts its anti-cancer effects primarily through the disruption of mitosis (NCI 2015). In mitochondria, paclitaxel induces apoptosis by dissipating the mitochondrial membrane potential, leading to cytochrome c release [301]. In addition, paclitaxel is shown to bind to the C-terminal ATPbinding site of HSP90, which is a region mediating macrophage activation. Interestingly, another anti-cancer drug cisplatin can also bind to the C-terminus of HSP90 [150,151,302]. A derivative of paclitaxel, nanoparticle-albumin-bound paclitaxel (nab-paclitaxel), exhibits reduced side effects and increased efficacy when treating cancers such as metastatic breast cancer [276]. Currently, over 3500 ongoing clinical trials are using paclitaxel to treat cancers, whether it is paclitaxel itself, derivatives such as nab-paclitaxel, or in combination with other drugs (NCT03315364 and NCT04137653).

\subsection{Targeting Proteins within Mitochondria}

Carboplatin is a second-generation chemotherapy modified from cisplatin to mitigate its side effects [277]. Both compounds are commonly employed in the clinic for treating patients with various types of cancers. These compounds possess the ability to target and disrupt nDNA via their platinum group, which induces DNA damages and subsequent apoptosis [278]. Importantly, both compounds also exert similar DNA-damaging effects on mtDNA, inducing mitochondrial ROS production and apoptosis [279,280]. Specifically, the treatment of ovarian cancer with cisplatin is known to induce mitochondrial ROS and disrupt the mitochondrial membrane, leading to the release of caspases and apoptosis [279]. Cisplatin can also induce an increase in the expression of the mitochondrial transcription factor, TFAM [279]. In laryngeal squamous cell carcinoma cells, carboplatin is shown to induce apoptosis via the upregulation of cytochrome $\mathrm{c}$ and PARP, as well as caspases 3,8 , and 9 [281].

ONC201 and its derivatives bind to CLPP, a protease in the matrix, and induce a proteotoxicity stress response, which eventually triggers mitochondrial failure and apoptosis [204]. As a single agent, ONC201 is capable of suppressing tumors with high expression of CLPP, including certain types of gliomas, endometrial cancer, prostate cancer, mantle cell lymphoma, and adrenal tumors [282]. One of its mechanisms of action is to inactivate the AKT/ERK stress response, which triggers the proapoptotic TNF-related apoptosis-inducing ligand in a wide range of cancer cell lines, including colon cancer and glioblastoma [303].

Clodronate is a pro-drug, which needs to be metabolized by the cell to generate the compound AppCCl 2 p to inhibit the adenine nucleotide transporter (ANT) in mitochondria [285]. ANT inhibition subsequently leads to the disruption of the mitochondrial membrane potential and eventually results in apoptosis. Clodronate is shown to be effective against breast cancer as well as its bone metastases [283,284].

Chlorambucil, another anti-cancer drug, disrupts normal mitochondrial function by alkylating mtDNA and subsequently inducing apoptosis [286,287]. Chlorambucil's potent ability to induce mtDNA damages allows its clinical application in treating cisplatinresistant cancers [288]. Although chlorambucil typically targets nDNA, with the addition of mitochondria-penetrating peptides (MPP), such as tri-phenyl phosphonium, it can 
traverse the mitochondrial membranes and attack mtDNA. In a similar manner, MPPs can be attached to other anti-cancer drugs to enable them to target the mitochondria effectively [304].

\subsection{Mitochondria-Targeting Molecules}

Tri-phenyl phosphonium (TPP) and its derivatives are lipophilic compounds that can be attached to anti-cancer drugs to act as mitochondria-targeting signals, thus facilitating their entry into the mitochondria [305]. Interestingly, TPP is capable of selectively targeting mitochondria of cancer stem cells, providing unique opportunities to investigate these cancerous mitochondria [306]. TPP has been tested for its conjugation to anti-cancer drugs, such as paclitaxel, and delivery to the mitochondria in HeLa cells in vitro and in murine mammary carcinomas in vivo, each showing promising efficiency and increased targeting [307,308].

Szeto-Schiller peptides and their derivatives also serve as attractive candidates for cancer drug delivery [309]. The Szeto-Schiller peptide can transverse the OMM and concentrate in the IMM. Its structure contains alternating sequences of amino acids and basic residues (e.g., tyrosine and dimethyl-tyrosine), enabling its ability to scavenge ROS and reduce their levels [290]. Its derivative, SS-31 (AKA Bendavia), has been shown to act like a drug, which targets cardiolipin, a phospholipid of the IMM that interacts with cytochrome $c$ and can treat heart failure [310-312]. Interestingly, SS-31 can protect mitochondrial cristae through its interaction with cardiolipin, suggesting its possible function in maintaining mitochondrial morphology [180]. While the use of Szeto-Schiller peptides reinforces the important role of mitochondria in disease in general, further research could exploit the ability of SS-31's derivatives in targeting cancers.

Pyridinium-based compounds represent another class of agents that selectively targets the mitochondria of cancer cells. In a hepatoblastoma cell line, pyridinium-substituted tetraphenylethylenes were shown to target the IMM, induce mitochondrial damages, and provoke cancer cell death through increased ROS, decreased membrane potentials, and impaired mitophagy [313]. Importantly, those with longer alkyl chains were proven to induce more morphological changes on the IMM [313]. Another example is the pyridinium and indole-linked F-16 compound, which damages mitochondria and exhibits efficacy against a broad range of cancers, as demonstrated by preclinical and clinical studies [314]. Although pyridinium salts can also target the ER, their mechanisms of action remain unclear [315].

Indolinium-based compounds, such as IR-780, can also target mitochondria. Both in vitro and in vivo studies show that IR-780 induced cancer cell apoptosis by targeting their mitochondria, including drug-resistant lung cancer cells [316]. IR-780 treatment in these cancer cells led to an increase in ROS and the depolarization of the mitochondrial membrane. Another indolinium-based compound is IR-Pyr, which is the intermediate product of an indole-based compound and pyridine, which serves as a part of photodynamic therapy - a light-based cancer treatment. IR-Pyr interacts with hyaluronic acid, a polysaccharide in the mitochondria capable of binding to hyaluronic acid receptors often overexpressed in cancer cells, and this interaction leads to the formation of aggregates detrimental to cancer cells [317].

\section{Future Perspectives}

Mitochondrial proteostasis and integrity are the foundation of cellular health, and dysfunctional mitochondria are intimately linked with human diseases including cancer [14]. Multiple pathways of MPQC exist at the molecular, organellar, and cellular level, seeking to monitor protein quality and repair damaged mitochondria. First, an MPQC surveillance mechanism hovers over mitochondrial precursors during their cytosolic translation and mitochondrial import. The mitoTAD, mitoCPR, and mitoRQC shape the mitochondrial proteome through steady-state turnover of mitochondrial precursors to ensure an appropriate stoichiometry between proteins encoded by nDNA and mtDNA, as well as their 
proper localization. Second, a large collection of chaperones and proteases reside inside mitochondria, working together to ensure protein folding and quantity. Third, excessive levels of misfolded and unfolded proteins in the mitochondrial matrix or a mito-nuclear protein imbalance activates a conserved UPR ${ }^{\mathrm{mt}}$, which functions to selectively induce a transcriptional response aimed at restoring mitochondrial proteostasis. In the event that the mitochondria cannot be repaired, options exist either to eliminate part of damaged mitochondria via MDVs or to remove the entire organelle through mitophagy. Elimination of the entire mitochondria is likely a last resort because it requires the cell to replace these damaged mitochondria.

As a metabolic disease, dysfunctional mitochondria are commonly observed in cancer. Despite almost century-long efforts in investigating the role of mitochondria in tumorigenesis, few anti-cancer drugs can effectively target mitochondria. Recently, altered MPQC has been linked with mitochondrial proteotoxicity and cancer. When hyperactivated, downregulated, or inactivated through mutations, many MPQC players are found to promote tumorigenesis, while others exert tumor suppressive or dual effects. In addition, a number of compounds have been tested for their ability to target specific MPQC regulators, demonstrating promising preclinical and/or clinical efficacy.

Despite our understanding of MPQC in regulating mitochondrial proteins and health, much of this knowledge was gathered through yeast studies. To effectively and safely translate these findings to bedside, further investigation and validation in higher eukaryotes, especially in those that can generate tumors, are needed. The development of novel technology to study and track live mitochondria and the application of innovative in vivo model systems can hasten this progress. A recent study demonstrated the feasibility of this approach, using positron emission topography and radiolabeled 4-fluorobenzyl-triphenylphosphonium to track the mitochondrial membrane in a mouse tumor model [318]. Given the established role of MPQC in cancer, MPQC-targeting compounds could provide opportunities for therapeutic testing, alone or in combination with standard therapy, to treat multiple types of cancer, as well as serving as tools to investigate mitochondrial biology. Undoubtedly, the development of these compounds and continued investigation of the fundamental mechanisms underlying MPQC in mitochondrial health and tumorigenesis hold promise to a new generation of anti-cancer drugs.

Author Contributions: Conceptualization: H.F., N.S. and S.K.; Writing: J.E.F., N.S., A.Z., S.K. and H.F.; Figures: J.E.F. and N.S.; Editing and revision: J.E.F., N.S., A.Z. and H.F. All authors have read and agreed to the published version of the manuscript.

Funding: This research received no external funding.

Institutional Review Board Statement: Not applicable.

Informed Consent Statement: Not applicable.

Data Availability Statement: Not applicable.

Acknowledgments: While the authors declare no conflicts of interest, we would like to thank Erika Beyer for discussion and inspiration on illustrating Figure 1, and Hongru Ni, Emily Hill, and Grace Meara for proofreading of the manuscript. Due to space limitations, we regret that we could not include all of the work of many colleagues in the field. H.F. acknowledges supports from the National Institute of Health (1UL1TR001430 and CA215059), the American Cancer Society (RSG17-204-01-TBG), and the National Science Foundation (1911253). J.E.F. and A.Z. are supported by the Undergraduate Research Opportunity Program from Boston University. N.S. acknowledges the training support from the National Heart, Lung, and Blood Institute (T32HL007501). S.K. was supported by a Dahod International Scholar grant from Boston University. The content of this article is solely the responsibility of the authors and does not necessarily represent the official views of the National Institute of Health.

Conflicts of Interest: The authors declare no conflict of interest. 


\section{References}

1. Ernster, L.; Schatz, G. Mitochondria: A historical review. J. Cell Biol. 1981, 91, 227s-255s. [CrossRef]

2. Anderson, A.J.; Jackson, T.D.; Stroud, D.A.; Stojanovski, D. Mitochondria-hubs for regulating cellular biochemistry: Emerging concepts and networks. Open Biol. 2019, 9, 190126. [CrossRef]

3. Hagstrom, E.; Freyer, C.; Battersby, B.J.; Stewart, J.B.; Larsson, N.G. No recombination of mtDNA after heteroplasmy for 50 generations in the mouse maternal germline. Nucleic Acids Res. 2014, 42, 1111-1116. [CrossRef] [PubMed]

4. Rius, R.; Cowley, M.J.; Riley, L.; Puttick, C.; Thorburn, D.R.; Christodoulou, J. Biparental inheritance of mitochondrial DNA in humans is not a common phenomenon. Genet. Med. 2019, 21, 2823-2826. [CrossRef]

5. Calvo, S.E.; Mootha, V.K. The mitochondrial proteome and human disease. Annu. Rev. Genomics Hum. Genet. 2010, 11, 25-44. [CrossRef]

6. Wiedemann, N.; Pfanner, N. Mitochondrial Machineries for Protein Import and Assembly. Annu. Rev. Biochem. 2017, 86, 685-714. [CrossRef] [PubMed]

7. Vazquez-Calvo, C.; Suhm, T.; Buttner, S.; Ott, M. The basic machineries for mitochondrial protein quality control. Mitochondrion 2020, 50, 121-131. [CrossRef]

8. Hu, J.; Dong, L.; Outten, C.E. The redox environment in the mitochondrial intermembrane space is maintained separately from the cytosol and matrix. J. Biol. Chem. 2008, 283, 29126-29134. [CrossRef]

9. Santo-Domingo, J.; Demaurex, N. Perspectives on: SGP symposium on mitochondrial physiology and medicine: The renaissance of mitochondrial pH. J. Gen. Physiol. 2012, 139, 415-423. [CrossRef] [PubMed]

10. Stefani, M. Protein misfolding and aggregation: New examples in medicine and biology of the dark side of the protein world. Biochim. Biophys. Acta 2004, 1739, 5-25. [CrossRef]

11. Chretien, D.; Benit, P.; Ha, H.H.; Keipert, S.; El-Khoury, R.; Chang, Y.T.; Jastroch, M.; Jacobs, H.T.; Rustin, P.; Rak, M. Mitochondria are physiologically maintained at close to 50 degrees C. PLoS Biol. 2018, 16, e2003992. [CrossRef] [PubMed]

12. Baeza, J.; Smallegan, M.J.; Denu, J.M. Site-specific reactivity of nonenzymatic lysine acetylation. ACS Chem. Biol. 2015, 10, 122-128. [CrossRef] [PubMed]

13. Wagner, G.R.; Payne, R.M. Widespread and enzyme-independent Nepsilon-acetylation and Nepsilon-succinylation of proteins in the chemical conditions of the mitochondrial matrix. J. Biol. Chem. 2013, 288, 29036-29045. [CrossRef] [PubMed]

14. Vyas, S.; Zaganjor, E.; Haigis, M.C. Mitochondria and Cancer. Cell 2016, 166, 555-566. [CrossRef]

15. Angelini, C.; Bello, L.; Spinazzi, M.; Ferrati, C. Mitochondrial disorders of the nuclear genome. Acta Myol. 2009, $28,16-23$.

16. Taylor, R.W.; Turnbull, D.M. Mitochondrial DNA mutations in human disease. Nat. Rev. Genet. 2005, 6, 389-402. [CrossRef]

17. Wallace, D.C. Mitochondria and cancer. Nat. Rev. Cancer 2012, 12, 685-698. [CrossRef]

18. Martin, W.F.; Garg, S.; Zimorski, V. Endosymbiotic theories for eukaryote origin. Philos. Trans. R. Soc. Lond. B Biol. Sci. 2015, 370, 20140330. [CrossRef]

19. Imachi, H.; Nobu, M.K.; Nakahara, N.; Morono, Y.; Ogawara, M.; Takaki, Y.; Takano, Y.; Uematsu, K.; Ikuta, T.; Ito, M.; et al. Isolation of an archaeon at the prokaryote-eukaryote interface. Nature 2020, 577, 519-525. [CrossRef]

20. Bjorkholm, P.; Harish, A.; Hagstrom, E.; Ernst, A.M.; Andersson, S.G. Mitochondrial genomes are retained by selective constraints on protein targeting. Proc. Natl. Acad. Sci. USA 2015, 112, 10154-10161. [CrossRef] [PubMed]

21. Pfanner, N.; Warscheid, B.; Wiedemann, N. Mitochondrial proteins: From biogenesis to functional networks. Nat. Rev. Mol. Cell Biol. 2019, 20, 267-284. [CrossRef] [PubMed]

22. Vardi-Oknin, D.; Arava, Y. Characterization of Factors Involved in Localized Translation Near Mitochondria by RibosomeProximity Labeling. Front. Cell Dev. Biol. 2019, 7, 305. [CrossRef]

23. Keyhani, E. Morphological changes in yeast cell mitochondria grown at various copper concentrations. Exp. Cell Res. 1973, 81, 73-78. [CrossRef]

24. Hansen, K.G.; Schlagowski, A.; Herrmann, J.M. Escorted by chaperones: Sti1 helps to usher precursor proteins from the ribosome to mitochondria. FEBS J. 2016, 283, 3335-3337. [CrossRef]

25. Wegele, H.; Wandinger, S.K.; Schmid, A.B.; Reinstein, J.; Buchner, J. Substrate Transfer from the Chaperone Hsp70 to Hsp90. J. Mol. Biol. 2006, 356, 802-811. [CrossRef]

26. Hansen, K.G.; Herrmann, J.M. Transport of Proteins into Mitochondria. Protein J. 2019, 38, 330-342. [CrossRef] [PubMed]

27. Hoseini, H.; Pandey, S.; Jores, T.; Schmitt, A.; Franz-Wachtel, M.; Macek, B.; Buchner, J.; Dimmer, K.S.; Rapaport, D. The cytosolic cochaperone Sti1 is relevant for mitochondrial biogenesis and morphology. FEBS J. 2016, 283, 3338-3352. [CrossRef] [PubMed]

28. Yamamoto, H.; Fukui, K.; Takahashi, H.; Kitamura, S.; Shiota, T.; Terao, K.; Uchida, M.; Esaki, M.; Nishikawa, S.; Yoshihisa, T.; et al. Roles of Tom70 in import of presequence-containing mitochondrial proteins. J. Biol. Chem. 2009, 284, 31635-31646. [CrossRef]

29. Schmidt, J.C.; Manhaes, L.; Fragoso, S.P.; Pavoni, D.P.; Krieger, M.A. Involvement of STI1 protein in the differentiation process of Trypanosoma cruzi. Parasitol. Int. 2018, 67, 131-139. [CrossRef]

30. Rohl, A.; Rohrberg, J.; Buchner, J. The chaperone Hsp90: Changing partners for demanding clients. Trends Biochem. Sci. 2013, 38, 253-262. [CrossRef]

31. Boos, F.; Kramer, L.; Groh, C.; Jung, F.; Haberkant, P.; Stein, F.; Wollweber, F.; Gackstatter, A.; Zoller, E.; van der Laan, M.; et al. Mitochondrial protein-induced stress triggers a global adaptive transcriptional programme. Nat. Cell Biol. 2019, $21,442-451$. [CrossRef] 
32. Bragoszewski, P.; Turek, M.; Chacinska, A. Control of mitochondrial biogenesis and function by the ubiquitin-proteasome system. Open Biol. 2017, 7, 170007. [CrossRef] [PubMed]

33. Vogtle, F.N.; Wortelkamp, S.; Zahedi, R.P.; Becker, D.; Leidhold, C.; Gevaert, K.; Kellermann, J.; Voos, W.; Sickmann, A.; Pfanner, N.; et al. Global analysis of the mitochondrial N-proteome identifies a processing peptidase critical for protein stability. Cell 2009, 139, 428-439. [CrossRef] [PubMed]

34. Kang, P.J.; Ostermann, J.; Shilling, J.; Neupert, W.; Craig, E.A.; Pfanner, N. Requirement for hsp70 in the mitochondrial matrix for translocation and folding of precursor proteins. Nature 1990, 348, 137-143. [CrossRef]

35. Fukasawa, Y.; Tsuji, J.; Fu, S.C.; Tomii, K.; Horton, P.; Imai, K. MitoFates: Improved prediction of mitochondrial targeting sequences and their cleavage sites. Mol. Cell. Proteomics 2015, 14, 1113-1126. [CrossRef] [PubMed]

36. Falkevall, A.; Alikhani, N.; Bhushan, S.; Pavlov, P.F.; Busch, K.; Johnson, K.A.; Eneqvist, T.; Tjernberg, L.; Ankarcrona, M.; Glaser, E. Degradation of the amyloid beta-protein by the novel mitochondrial peptidasome, PreP. J. Biol. Chem. 2006, 281, 29096-29104. [CrossRef]

37. Pfeffer, S.; Woellhaf, M.W.; Herrmann, J.M.; Forster, F. Organization of the mitochondrial translation machinery studied in situ by cryoelectron tomography. Nat. Commun. 2015, 6, 6019. [CrossRef] [PubMed]

38. Sirrenberg, C.; Bauer, M.F.; Guiard, B.; Neupert, W.; Brunner, M. Import of carrier proteins into the mitochondrial inner membrane mediated by Tim22. Nature 1996, 384, 582-585. [CrossRef]

39. Callegari, S.; Muller, T.; Schulz, C.; Lenz, C.; Jans, D.C.; Wissel, M.; Opazo, F.; Rizzoli, S.O.; Jakobs, S.; Urlaub, H.; et al. A MICOS-TIM22 Association Promotes Carrier Import into Human Mitochondria. J. Mol. Biol. 2019, 431, 2835-2851. [CrossRef]

40. Gornicka, A.; Bragoszewski, P.; Chroscicki, P.; Wenz, L.S.; Schulz, C.; Rehling, P.; Chacinska, A. A discrete pathway for the transfer of intermembrane space proteins across the outer membrane of mitochondria. Mol. Biol. Cell 2014, 25, 3999-4009. [CrossRef]

41. Mesecke, N.; Terziyska, N.; Kozany, C.; Baumann, F.; Neupert, W.; Hell, K.; Herrmann, J.M. A disulfide relay system in the intermembrane space of mitochondria that mediates protein import. Cell 2005, 121, 1059-1069. [CrossRef]

42. Doan, K.N.; Grevel, A.; Martensson, C.U.; Ellenrieder, L.; Thornton, N.; Wenz, L.S.; Opalinski, L.; Guiard, B.; Pfanner, N.; Becker, T. The Mitochondrial Import Complex MIM Functions as Main Translocase for alpha-Helical Outer Membrane Proteins. Cell Rep. 2020, 31, 107567. [CrossRef]

43. Hohr, A.I.; Straub, S.P.; Warscheid, B.; Becker, T.; Wiedemann, N. Assembly of beta-barrel proteins in the mitochondrial outer membrane. Biochim. Biophys. Acta 2015, 1853, 74-88. [CrossRef]

44. Hohr, A.I.C.; Lindau, C.; Wirth, C.; Qiu, J.; Stroud, D.A.; Kutik, S.; Guiard, B.; Hunte, C.; Becker, T.; Pfanner, N.; et al. Membrane protein insertion through a mitochondrial beta-barrel gate. Science 2018, 359, eaah6834. [CrossRef] [PubMed]

45. Scheffler, I.E. Mitochondria; Wiley-Liss: New York, NY, USA, 2007.

46. Boczonadi, V.; Horvath, R. Mitochondria: Impaired mitochondrial translation in human disease. Int. J. Biochem. Cell Biol. 2014, 48, 77-84. [CrossRef] [PubMed]

47. D'Souza, A.R.; Minczuk, M. Mitochondrial transcription and translation: Overview. Essays Biochem. 2018, 62, 309-320.

48. Minczuk, M.; He, J.; Duch, A.M.; Ettema, T.J.; Chlebowski, A.; Dzionek, K.; Nijtmans, L.G.; Huynen, M.A.; Holt, I.J. TEFM (c17orf42) is necessary for transcription of human mtDNA. Nucleic Acids Res. 2011, 39, 4284-4299. [CrossRef]

49. Lapkouski, M.; Hallberg, B.M. Structure of mitochondrial poly(A) RNA polymerase reveals the structural basis for dimerization, ATP selectivity and the SPAX4 disease phenotype. Nucleic Acids Res. 2015, 43, 9065-9075. [CrossRef] [PubMed]

50. Christian, B.E.; Spremulli, L.L. Mechanism of protein biosynthesis in mammalian mitochondria. Biochim. Biophys. Acta 2012, 1819, 1035-1054. [CrossRef]

51. Tomal, A.; Kwasniak-Owczarek, M.; Janska, H. An Update on Mitochondrial Ribosome Biology: The Plant Mitoribosome in the Spotlight. Cells 2019, 8, 1562. [CrossRef]

52. Li, Y.; Sharma, M.R.; Koripella, R.K.; Yang, Y.; Kaushal, P.S.; Lin, Q.; Wade, J.T.; Gray, T.A.; Derbyshire, K.M.; Agrawal, R.K.; et al. Zinc depletion induces ribosome hibernation in mycobacteria. Proc. Natl. Acad. Sci. USA 2018, 115, 8191-8196. [CrossRef] [PubMed]

53. Greber, B.J.; Ban, N. Structure and Function of the Mitochondrial Ribosome. Annu. Rev. Biochem. 2016, 85, 103-132. [CrossRef]

54. Christian, B.E.; Spremulli, L.L. Preferential selection of the $5^{\prime}$-terminal start codon on leaderless mRNAs by mammalian mitochondrial ribosomes. J. Biol. Chem. 2010, 285, 28379-28386. [CrossRef] [PubMed]

55. Lightowlers, R.N.; Rozanska, A.; Chrzanowska-Lightowlers, Z.M. Mitochondrial protein synthesis: Figuring the fundamentals, complexities and complications, of mammalian mitochondrial translation. FEBS Lett. 2014, 588, 2496-2503. [CrossRef]

56. Mai, N.; Chrzanowska-Lightowlers, Z.M.; Lightowlers, R.N. The process of mammalian mitochondrial protein synthesis. Cell Tissue Res. 2017, 367, 5-20. [CrossRef] [PubMed]

57. Rorbach, J.; Richter, R.; Wessels, H.J.; Wydro, M.; Pekalski, M.; Farhoud, M.; Kuhl, I.; Gaisne, M.; Bonnefoy, N.; Smeitink, J.A.; et al. The human mitochondrial ribosome recycling factor is essential for cell viability. Nucleic Acids Res. 2008, 36, 5787-5799. [CrossRef]

58. Rorbach, J.; Yusoff, A.A.; Tuppen, H.; Abg-Kamaludin, D.P.; Chrzanowska-Lightowlers, Z.M.; Taylor, R.W.; Turnbull, D.M.; McFarland, R.; Lightowlers, R.N. Overexpression of human mitochondrial valyl tRNA synthetase can partially restore levels of cognate mt-tRNAVal carrying the pathogenic C25U mutation. Nucleic Acids Res. 2008, 36, 3065-3074. [CrossRef]

59. Weraarpachai, W.; Antonicka, H.; Sasarman, F.; Seeger, J.; Schrank, B.; Kolesar, J.E.; Lochmuller, H.; Chevrette, M.; Kaufman, B.A.; Horvath, R.; et al. Mutation in TACO1, encoding a translational activator of COX I, results in cytochrome c oxidase deficiency and late-onset Leigh syndrome. Nat. Genet. 2009, 41, 833-837. [CrossRef] 
60. Song, J.; Herrmann, J.M.; Becker, T. Quality control of the mitochondrial proteome. Nat. Rev. Mol. Cell Biol. 2021, 22, 54-70. [CrossRef]

61. Barbour, J.A.; Turner, N. Mitochondrial Stress Signaling Promotes Cellular Adaptations. Int. J. Cell Biol. 2014, $2014,156020$. [CrossRef]

62. McLelland, G.L.; Soubannier, V.; Chen, C.X.; McBride, H.M.; Fon, E.A. Parkin and PINK1 function in a vesicular trafficking pathway regulating mitochondrial quality control. EMBO J. 2014, 33, 282-295. [CrossRef]

63. Twig, G.; Elorza, A.; Molina, A.J.; Mohamed, H.; Wikstrom, J.D.; Walzer, G.; Stiles, L.; Haigh, S.E.; Katz, S.; Las, G.; et al. Fission and selective fusion govern mitochondrial segregation and elimination by autophagy. EMBO J. 2008, 27, 433-446. [CrossRef]

64. Yamashita, S.I.; Jin, X.; Furukawa, K.; Hamasaki, M.; Nezu, A.; Otera, H.; Saigusa, T.; Yoshimori, T.; Sakai, Y.; Mihara, K.; et al. Mitochondrial division occurs concurrently with autophagosome formation but independently of Drp1 during mitophagy. J. Cell Biol. 2016, 215, 649-665. [CrossRef]

65. Martensson, C.U.; Priesnitz, C.; Song, J.; Ellenrieder, L.; Doan, K.N.; Boos, F.; Floerchinger, A.; Zufall, N.; Oeljeklaus, S.; Warscheid, B.; et al. Mitochondrial protein translocation-associated degradation. Nature 2019, 569, 679-683. [CrossRef] [PubMed]

66. Neuber, O.; Jarosch, E.; Volkwein, C.; Walter, J.; Sommer, T. Ubx2 links the Cdc48 complex to ER-associated protein degradation. Nat. Cell Biol. 2005, 7, 993-998. [CrossRef]

67. Schuberth, C.; Buchberger, A. Membrane-bound Ubx2 recruits Cdc48 to ubiquitin ligases and their substrates to ensure efficient ER-associated protein degradation. Nat. Cell Biol. 2005, 7, 999-1006. [CrossRef]

68. Wang, X.; Chen, X.J. A cytosolic network suppressing mitochondria-mediated proteostatic stress and cell death. Nature 2015, 524, 481-484. [CrossRef] [PubMed]

69. Wrobel, L.; Topf, U.; Bragoszewski, P.; Wiese, S.; Sztolsztener, M.E.; Oeljeklaus, S.; Varabyova, A.; Lirski, M.; Chroscicki, P.; Mroczek, S.; et al. Mistargeted mitochondrial proteins activate a proteostatic response in the cytosol. Nature 2015, 524, 485-488. [CrossRef]

70. Hill, K.; Model, K.; Ryan, M.T.; Dietmeier, K.; Martin, F.; Wagner, R.; Pfanner, N. Tom40 forms the hydrophilic channel of the mitochondrial import pore for preproteins [see comment]. Nature 1998, 395, 516-521. [CrossRef]

71. Kiebler, M.; Pfaller, R.; Sollner, T.; Griffiths, G.; Horstmann, H.; Pfanner, N.; Neupert, W. Identification of a mitochondrial receptor complex required for recognition and membrane insertion of precursor proteins. Nature 1990, 348, 610-616. [CrossRef] [PubMed]

72. Waegemann, K.; Popov-Celeketic, D.; Neupert, W.; Azem, A.; Mokranjac, D. Cooperation of TOM and TIM23 complexes during translocation of proteins into mitochondria. J. Mol. Biol. 2015, 427, 1075-1084. [CrossRef] [PubMed]

73. Shiota, T.; Imai, K.; Qiu, J.; Hewitt, V.L.; Tan, K.; Shen, H.H.; Sakiyama, N.; Fukasawa, Y.; Hayat, S.; Kamiya, M.; et al. Molecular architecture of the active mitochondrial protein gate. Science 2015, 349, 1544-1548. [CrossRef]

74. Yamano, K.; Yatsukawa, Y.; Esaki, M.; Hobbs, A.E.; Jensen, R.E.; Endo, T. Tom20 and Tom22 share the common signal recognition pathway in mitochondrial protein import. J. Biol. Chem. 2008, 283, 3799-3807. [CrossRef]

75. Page, T.J.; Sikder, D.; Yang, L.; Pluta, L.; Wolfinger, R.D.; Kodadek, T.; Thomas, R.S. Genome-wide analysis of human HSF1 signaling reveals a transcriptional program linked to cellular adaptation and survival. Mol. Biosyst. 2006, 2, 627-639. [CrossRef]

76. Weidberg, H.; Amon, A. MitoCPR-A surveillance pathway that protects mitochondria in response to protein import stress. Science 2018, 360, eaan4146. [CrossRef]

77. Chen, Y.C.; Umanah, G.K.; Dephoure, N.; Andrabi, S.A.; Gygi, S.P.; Dawson, T.M.; Dawson, V.L.; Rutter, J. Msp1/ATAD1 maintains mitochondrial function by facilitating the degradation of mislocalized tail-anchored proteins. EMBO J. 2014, 33, 1548-1564. [CrossRef]

78. Okreglak, V.; Walter, P. The conserved AAA-ATPase Msp1 confers organelle specificity to tail-anchored proteins. Proc. Natl. Acad. Sci. USA 2014, 111, 8019-8024. [CrossRef]

79. Weir, N.R.; Kamber, R.A.; Martenson, J.S.; Denic, V. The AAA protein Msp1 mediates clearance of excess tail-anchored proteins from the peroxisomal membrane. Elife 2017, 6, e28507. [CrossRef]

80. Brandman, O.; Hegde, R.S. Ribosome-associated protein quality control. Nat. Struct Mol. Biol. 2016, 23, 7-15. [CrossRef]

81. Defenouillere, Q.; Yao, Y.; Mouaikel, J.; Namane, A.; Galopier, A.; Decourty, L.; Doyen, A.; Malabat, C.; Saveanu, C.; Jacquier, A.; et al. Cdc48-associated complex bound to $60 \mathrm{~S}$ particles is required for the clearance of aberrant translation products. Proc. Natl. Acad. Sci. USA 2013, 110, 5046-5051. [CrossRef]

82. Izawa, T.; Tsuboi, T.; Kuroha, K.; Inada, T.; Nishikawa, S.; Endo, T. Roles of dom34:hbs1 in nonstop protein clearance from translocators for normal organelle protein influx. Cell Rep. 2012, 2, 447-453. [CrossRef]

83. Izawa, T.; Park, S.H.; Zhao, L.; Hartl, F.U.; Neupert, W. Cytosolic Protein Vms1 Links Ribosome Quality Control to Mitochondrial and Cellular Homeostasis. Cell 2017, 171, 890-903. [CrossRef]

84. Bukau, B.; Weissman, J.; Horwich, A. Molecular chaperones and protein quality control. Cell 2006, 125, 443-451. [CrossRef] [PubMed]

85. Voos, W. Chaperone-protease networks in mitochondrial protein homeostasis. Biochim. Biophys. Acta 2013, 1833, 388-399. [CrossRef] [PubMed]

86. Craig, E.A. Hsp70 at the membrane: Driving protein translocation. BMC Biol. 2018, 16, 11. [CrossRef] [PubMed]

87. Westermann, B.; Gaume, B.; Herrmann, J.M.; Neupert, W.; Schwarz, E. Role of the mitochondrial DnaJ. homolog Mdj1p as a chaperone for mitochondrially synthesized and imported proteins. Mol. Cell Biol. 1996, 16, 7063-7071. [CrossRef] 
88. Horst, M.; Oppliger, W.; Rospert, S.; Schonfeld, H.J.; Schatz, G.; Azem, A. Sequential action of two hsp70 complexes during protein import into mitochondria. EMBO J. 1997, 16, 1842-1849. [CrossRef]

89. Ostermann, J.; Horwich, A.L.; Neupert, W.; Hartl, F.U. Protein folding in mitochondria requires complex formation with hsp60 and ATP hydrolysis. Nature 1989, 341, 125-130. [CrossRef]

90. Rospert, S.; Looser, R.; Dubaquie, Y.; Matouschek, A.; Glick, B.S.; Schatz, G. Hsp60-independent protein folding in the matrix of yeast mitochondria. EMBO J. 1996, 15, 764-774. [CrossRef] [PubMed]

91. Walter, S. Structure and function of the GroE chaperone. Cell Mol. Life Sci. 2002, 59, 1589-1597. [CrossRef]

92. Weiss, C.; Jebara, F.; Nisemblat, S.; Azem, A. Dynamic Complexes in the Chaperonin-Mediated Protein Folding Cycle. Front Mol. Biosci 2016, 3, 80. [CrossRef]

93. Dubaquie, Y.; Looser, R.; Rospert, S. Significance of chaperonin 10-mediated inhibition of ATP hydrolysis by chaperonin 60. Proc. Natl. Acad. Sci. USA 1997, 94, 9011-9016. [CrossRef]

94. Schumacher, R.J.; Hansen, W.J.; Freeman, B.C.; Alnemri, E.; Litwack, G.; Toft, D.O. Cooperative action of Hsp70, Hsp90, and DnaJ. proteins in protein renaturation. Biochemistry 1996, 35, 14889-14898. [CrossRef]

95. Johnson, B.D.; Schumacher, R.J.; Ross, E.D.; Toft, D.O. Hop modulates Hsp70/Hsp90 interactions in protein folding. J. Biol. Chem. 1998, 273, 3679-3686. [CrossRef]

96. Moran Luengo, T.; Kityk, R.; Mayer, M.P.; Rudiger, S.G.D. Hsp90 Breaks the Deadlock of the Hsp70 Chaperone System. Mol. Cell 2018, 70, 545-552. [CrossRef]

97. Puchades, C.; Rampello, A.J.; Shin, M.; Giuliano, C.J.; Wiseman, R.L.; Glynn, S.E.; Lander, G.C. Structure of the mitochondrial inner membrane AAA+ protease YME1 gives insight into substrate processing. Science 2017, 358, eaao0464. [CrossRef]

98. Puchades, C.; Ding, B.; Song, A.; Wiseman, R.L.; Lander, G.C.; Glynn, S.E. Unique Structural Features of the Mitochondrial AAA+ Protease AFG3L2 Reveal the Molecular Basis for Activity in Health and Disease. Mol. Cell 2019, 75, 1073-1085. [CrossRef]

99. Arlt, H.; Steglich, G.; Perryman, R.; Guiard, B.; Neupert, W.; Langer, T. The formation of respiratory chain complexes in mitochondria is under the proteolytic control of the m-AAA protease. EMBO J. 1998, 17, 4837-4847. [CrossRef] [PubMed]

100. Augustin, S.; Nolden, M.; Muller, S.; Hardt, O.; Arnold, I.; Langer, T. Characterization of peptides released from mitochondria: Evidence for constant proteolysis and peptide efflux. J. Biol. Chem. 2005, 280, 2691-2699. [CrossRef]

101. Baker, M.J.; Mooga, V.P.; Guiard, B.; Langer, T.; Ryan, M.T.; Stojanovski, D. Impaired folding of the mitochondrial small TIM chaperones induces clearance by the i-AAA protease. J. Mol. Biol. 2012, 424, 227-239. [CrossRef]

102. Anand, R.; Wai, T.; Baker, M.J.; Kladt, N.; Schauss, A.C.; Rugarli, E.; Langer, T. The i-AAA protease YME1L and OMA1 cleave OPA1 to balance mitochondrial fusion and fission. J. Cell Biol. 2014, 204, 919-929. [CrossRef] [PubMed]

103. Rainbolt, T.K.; Lebeau, J.; Puchades, C.; Wiseman, R.L. Reciprocal Degradation of YME1L and OMA1 Adapts Mitochondrial Proteolytic Activity during Stress. Cell Rep. 2016, 14, 2041-2049. [CrossRef]

104. Zhang, K.; Li, H.; Song, Z. Membrane depolarization activates the mitochondrial protease OMA1 by stimulating self-cleavage. EMBO Rep. 2014, 15, 576-585. [CrossRef] [PubMed]

105. Bender, T.; Lewrenz, I.; Franken, S.; Baitzel, C.; Voos, W. Mitochondrial enzymes are protected from stress-induced aggregation by mitochondrial chaperones and the Pim1/LON protease. Mol. Biol. Cell 2011, 22, 541-554. [CrossRef]

106. Fischer, F.; Langer, J.D.; Osiewacz, H.D. Identification of potential mitochondrial CLPXP protease interactors and substrates suggests its central role in energy metabolism. Sci. Rep. 2015, 5, 18375. [CrossRef]

107. Liu, K.; Ologbenla, A.; Houry, W.A. Dynamics of the ClpP serine protease: A model for self-compartmentalized proteases. Crit. Rev. Biochem. Mol. Biol. 2014, 49, 400-412. [CrossRef]

108. Kirstein, J.; Moliere, N.; Dougan, D.A.; Turgay, K. Adapting the machine: Adaptor proteins for Hsp100/Clp and AAA+ proteases. Nat. Rev. Microbiol 2009, 7, 589-599. [CrossRef]

109. Zhao, Q.; Wang, J.; Levichkin, I.V.; Stasinopoulos, S.; Ryan, M.T.; Hoogenraad, N.J. A mitochondrial specific stress response in mammalian cells. EMBO J. 2002, 21, 4411-4419. [CrossRef]

110. Goldberg, A.L.; Waxman, L. The role of ATP hydrolysis in the breakdown of proteins and peptides by protease La from Escherichia coli. J. Biol. Chem. 1985, 260, 12029-12034. [CrossRef]

111. Cha, S.S.; An, Y.J.; Lee, C.R.; Lee, H.S.; Kim, Y.G.; Kim, S.J.; Kwon, K.K.; De Donatis, G.M.; Lee, J.H.; Maurizi, M.R.; et al. Crystal structure of Lon protease: Molecular architecture of gated entry to a sequestered degradation chamber. EMBO J. 2010, 29, 3520-3530. [CrossRef]

112. Desautels, M.; Goldberg, A.L. Demonstration of an ATP-dependent, vanadate-sensitive endoprotease in the matrix of rat liver mitochondria. J. Biol. Chem. 1982, 257, 11673-11679. [CrossRef]

113. Bota, D.A.; Davies, K.J. Lon protease preferentially degrades oxidized mitochondrial aconitase by an ATP-stimulated mechanism. Nat. Cell Biol. 2002, 4, 674-680. [CrossRef]

114. Haynes, C.M.; Yang, Y.; Blais, S.P.; Neubert, T.A.; Ron, D. The matrix peptide exporter HAF-1 signals a mitochondrial UPR by activating the transcription factor ZC376.7 in C. elegans. Mol. Cell 2010, 37, 529-540. [CrossRef]

115. Nargund, A.M.; Pellegrino, M.W.; Fiorese, C.J.; Baker, B.M.; Haynes, C.M. Mitochondrial import efficiency of ATFS-1 regulates mitochondrial UPR activation. Science 2012, 337, 587-590. [CrossRef]

116. Rolland, S.G.; Schneid, S.; Schwarz, M.; Rackles, E.; Fischer, C.; Haeussler, S.; Regmi, S.G.; Yeroslaviz, A.; Habermann, B.; Mokranjac, D.; et al. Compromised Mitochondrial Protein Import Acts as a Signal for UPR(mt). Cell Rep. 2019, 28, 1659-1669. [CrossRef] 
117. Melber, A.; Haynes, C.M. UPR(mt) regulation and output: A stress response mediated by mitochondrial-nuclear communication. Cell Res. 2018, 28, 281-295. [CrossRef] [PubMed]

118. Pakos-Zebrucka, K.; Koryga, I.; Mnich, K.; Ljujic, M.; Samali, A.; Gorman, A.M. The integrated stress response. EMBO Rep. 2016, 17, 1374-1395. [CrossRef]

119. Taniuchi, S.; Miyake, M.; Tsugawa, K.; Oyadomari, M.; Oyadomari, S. Integrated stress response of vertebrates is regulated by four eIF2alpha kinases. Sci. Rep. 2016, 6, 32886. [CrossRef]

120. Teske, B.F.; Fusakio, M.E.; Zhou, D.; Shan, J.; McClintick, J.N.; Kilberg, M.S.; Wek, R.C. CHOP induces activating transcription factor 5 (ATF5) to trigger apoptosis in response to perturbations in protein homeostasis. Mol. Biol. Cell 2013, 24, $2477-2490$. [CrossRef]

121. Zhou, D.; Palam, L.R.; Jiang, L.; Narasimhan, J.; Staschke, K.A.; Wek, R.C. Phosphorylation of eIF2 directs ATF5 translational control in response to diverse stress conditions. J. Biol. Chem. 2008, 283, 7064-7073. [CrossRef]

122. Vattem, K.M.; Wek, R.C. Reinitiation involving upstream ORFs regulates ATF4 mRNA translation in mammalian cells. Proc. Natl. Acad. Sci. USA 2004, 101, 11269-11274. [CrossRef]

123. Quiros, P.M.; Prado, M.A.; Zamboni, N.; D'Amico, D.; Williams, R.W.; Finley, D.; Gygi, S.P.; Auwerx, J. Multi-omics analysis identifies ATF4 as a key regulator of the mitochondrial stress response in mammals. J. Cell Biol. 2017, 216, 2027-2045. [CrossRef]

124. Guo, X.; Aviles, G.; Liu, Y.; Tian, R.; Unger, B.A.; Lin, Y.T.; Wiita, A.P.; Xu, K.; Correia, M.A.; Kampmann, M. Mitochondrial stress is relayed to the cytosol by an OMA1-DELE1-HRI pathway. Nature 2020, 579, 427-432. [CrossRef]

125. Fessler, E.; Eckl, E.M.; Schmitt, S.; Mancilla, I.A.; Meyer-Bender, M.F.; Hanf, M.; Philippou-Massier, J.; Krebs, S.; Zischka, H.; Jae, L.T. A pathway coordinated by DELE1 relays mitochondrial stress to the cytosol. Nature 2020, 579, 433-437. [CrossRef]

126. Pickles, S.; Vigie, P.; Youle, R.J. Mitophagy and Quality Control Mechanisms in Mitochondrial Maintenance. Curr. Biol. 2018, 28, R170-R185. [CrossRef]

127. Jin, S.M.; Lazarou, M.; Wang, C.; Kane, L.A.; Narendra, D.P.; Youle, R.J. Mitochondrial membrane potential regulates PINK1 import and proteolytic destabilization by PARL. J. Cell Biol. 2010, 191, 933-942. [CrossRef]

128. Yamano, K.; Youle, R.J. PINK1 is degraded through the N-end rule pathway. Autophagy 2013, 9, 1758-1769. [CrossRef]

129. Kane, L.A.; Lazarou, M.; Fogel, A.I.; Li, Y.; Yamano, K.; Sarraf, S.A.; Banerjee, S.; Youle, R.J. PINK1 phosphorylates ubiquitin to activate Parkin E3 ubiquitin ligase activity. J. Cell Biol. 2014, 205, 143-153. [CrossRef]

130. Sugiura, A.; McLelland, G.L.; Fon, E.A.; McBride, H.M. A new pathway for mitochondrial quality control: Mitochondrial-derived vesicles. EMBO J. 2014, 33, 2142-2156. [CrossRef]

131. Neuspiel, M.; Schauss, A.C.; Braschi, E.; Zunino, R.; Rippstein, P.; Rachubinski, R.A.; Andrade-Navarro, M.A.; McBride, H.M. Cargo-selected transport from the mitochondria to peroxisomes is mediated by vesicular carriers. Curr. Biol. 2008, 18, 102-108. [CrossRef]

132. Warburg, O. On respiratory impairment in cancer cells. Science 1956, 124, 269-270.

133. Warburg, O. On the origin of cancer cells. Science 1956, 123, 309-314. [CrossRef]

134. Hunter, J.C.; Burk, D.; Woods, M.W. Influence of diphosphopyridine nucleotide (DPN) on photodynamic effects of low concentrations of methylene blue in ascites tumor cells. J. Natl. Cancer Inst. 1967, 39, 587-593.

135. Seyfried, T.N. Cancer as a mitochondrial metabolic disease. Front. Cell Dev. Biol. 2015, 3, 43. [CrossRef] [PubMed]

136. Althubaiti, S.; Karwath, A.; Dallol, A.; Noor, A.; Alkhayyat, S.S.; Alwassia, R.; Mineta, K.; Gojobori, T.; Beggs, A.D.; Schofield, P.N.; et al. Ontology-based prediction of cancer driver genes. Sci. Rep. 2019, 9, 17405. [CrossRef]

137. Wang, H.; Han, H.; Mousses, S.; Von Hoff, D.D. Targeting loss-of-function mutations in tumor-suppressor genes as a strategy for development of cancer therapeutic agents. Semin Oncol. 2006, 33, 513-520. [CrossRef] [PubMed]

138. van Belzen, N.; Diesveld, M.P.; van der Made, A.C.; Nozawa, Y.; Dinjens, W.N.; Vlietstra, R.; Trapman, J.; Bosman, F.T. Identification of mRNAs that show modulated expression during colon carcinoma cell differentiation. Eur. J. Biochem. 1995, 234, 843-848. [CrossRef]

139. Wang, Z.; Li, J.; Long, X.; Jiao, L.; Zhou, M.; Wu, K. MRPS16 facilitates tumor progression via the PI3K/AKT/Snail signaling axis. J. Cancer 2020, 11, 2032-2043. [CrossRef] [PubMed]

140. Lazar, V.; Suo, C.; Orear, C.; van den Oord, J.; Balogh, Z.; Guegan, J.; Job, B.; Meurice, G.; Ripoche, H.; Calza, S.; et al. Integrated molecular portrait of non-small cell lung cancers. BMC Med. Genomics 2013, 6, 53. [CrossRef]

141. Sotgia, F.; Whitaker-Menezes, D.; Martinez-Outschoorn, U.E.; Salem, A.F.; Tsirigos, A.; Lamb, R.; Sneddon, S.; Hulit, J.; Howell, A.; Lisanti, M.P. Mitochondria "fuel" breast cancer metabolism: Fifteen markers of mitochondrial biogenesis label epithelial cancer cells, but are excluded from adjacent stromal cells. Cell Cycle 2012, 11, 4390-4401. [CrossRef]

142. Kadonosono, T.; Kato, M.; Ueda, M. Metallopeptidase, neurolysin, as a novel molecular tool for analysis of properties of cancer-producing matrix metalloproteinases-2 and -9. Appl. Microbiol. Biotechnol. 2007, 75, 1285-1291. [CrossRef] [PubMed]

143. Mirali, S.; Botham, A.; Voisin, V.; Xu, C.; St-Germain, J.; Sharon, D.; Hoff, F.W.; Qiu, Y.; Hurren, R.; Gronda, M.; et al. The mitochondrial peptidase, neurolysin, regulates respiratory chain supercomplex formation and is necessary for AML viability. Sci. Transl. Med. 2020, 12, eaaz8264. [CrossRef]

144. Abe, M.; Manola, J.B.; Oh, W.K.; Parslow, D.L.; George, D.J.; Austin, C.L.; Kantoff, P.W. Plasma levels of heat shock protein 70 in patients with prostate cancer: A potential biomarker for prostate cancer. Clin. Prostate Cancer 2004, 3, 49-53. [CrossRef] [PubMed]

145. Hwang, T.S.; Han, H.S.; Choi, H.K.; Lee, Y.J.; Kim, Y.-J.; Han, M.-Y.; Park, Y.-M. Differential, stage-dependent expression of Hsp70, Hsp110 and Bcl-2 in colorectal cancer. J. Gastroenterol. Hepatol. 2003, 18, 690-700. [CrossRef] 
146. Lazaris, A.C.; Theodoropoulos, G.E.; Aroni, K.; Saetta, A.; Davaris, P.S. Immunohistochemical expression of C-myc oncogene, heat shock protein 70 and HLA-DR molecules in malignant cutaneous melanoma. Virchows Archiv 1995, 426, 461-467. [CrossRef]

147. Athanassiadou, P.; Petrakakou, E.; Sakelariou, V.; Zerva, C.; Liossi, A.; Michalas, S.; Athanassiades, P. Expression of p53, bcl-2 and heat shock protein (hsp72) in malignant and benign ovarian tumours. Eur. J. Cancer Prev. 1998, 7, 225-231. [CrossRef]

148. Chuma, M.; Sakamoto, M.; Yamazaki, K.; Ohta, T.; Ohki, M.; Asaka, M.; Hirohashi, S. Expression profiling in multistage hepatocarcinogenesis: Identification of HSP70 as a molecular marker of early hepatocellular carcinoma. Hepatology 2003, 37, 198-207. [CrossRef] [PubMed]

149. Young, J.C.; Hoogenraad, N.J.; Hartl, F.U. Molecular Chaperones Hsp90 and Hsp70 Deliver Preproteins to the Mitochondrial Import Receptor Tom70. Cell 2003, 112, 41-50. [CrossRef]

150. Donnelly, A.; Blagg, B.S. Novobiocin and additional inhibitors of the Hsp90 C-terminal nucleotide-binding pocket. Curr. Med. Chem. 2008, 15, 2702-2717. [CrossRef] [PubMed]

151. Garg, G.; Khandelwal, A.; Blagg, B.S. Anticancer Inhibitors of Hsp90 Function: Beyond the Usual Suspects. Adv. Cancer Res. 2016, $129,51-88$

152. Xu, Q.; Tu, J.; Dou, C.; Zhang, J.; Yang, L.; Liu, X.; Lei, K.; Liu, Z.; Wang, Y.; Li, L.; et al. HSP90 promotes cell glycolysis, proliferation and inhibits apoptosis by regulating PKM2 abundance via Thr-328 phosphorylation in hepatocellular carcinoma. Mol. Cancer 2017, 16, 178. [CrossRef] [PubMed]

153. Siegelin, M.D. Inhibition of the mitochondrial Hsp90 chaperone network: A novel, efficient treatment strategy for cancer? Cancer Lett. 2013, 333, 133-146. [CrossRef]

154. Powers, M.V.; Clarke, P.A.; Workman, P. Dual targeting of HSC70 and HSP72 inhibits HSP90 function and induces tumor-specific apoptosis. Cancer Cell 2008, 14, 250-262. [CrossRef]

155. Chen, Z.; Sasaki, T.; Tan, X.; Carretero, J.; Shimamura, T.; Li, D.; Xu, C.; Wang, Y.; Adelmant, G.O.; Capelletti, M.; et al. Inhibition of ALK, PI3K/MEK, and HSP90 in Murine Lung Adenocarcinoma Induced by EML4-ALK Fusion Oncogene. Cancer Res. 2010, 70, 9827. [CrossRef] [PubMed]

156. Singh, K.K.; Ayyasamy, V.; Owens, K.M.; Koul, M.S.; Vujcic, M. Mutations in mitochondrial DNA polymerase-gamma promote breast tumorigenesis. J. Hum. Genet. 2009, 54, 516-524. [CrossRef]

157. Singh, B.; Owens, K.M.; Bajpai, P.; Desouki, M.M.; Srinivasasainagendra, V.; Tiwari, H.K.; Singh, K.K. Mitochondrial DNA Polymerase POLG1 Disease Mutations and Germline Variants Promote Tumorigenic Properties. PLoS ONE 2015, 10, e0139846. [CrossRef]

158. Lee, H.C.; Yin, P.H.; Lin, J.C.; Wu, C.C.; Chen, C.Y.; Wu, C.W.; Chi, C.W.; Tam, T.N.; Wei, Y.H. Mitochondrial genome instability and mtDNA depletion in human cancers. Ann. N. Y. Acad. Sci. 2005, 1042, 109-122. [CrossRef]

159. Richter, R.; Rorbach, J.; Pajak, A.; Smith, P.M.; Wessels, H.J.; Huynen, M.A.; Smeitink, J.A.; Lightowlers, R.N.; Chrzanowska-Lightowlers, Z.M. A functional peptidyl-tRNA hydrolase, ICT1, has been recruited into the human mitochondrial ribosome. EMBO J. 2010, 29, 1116-1125. [CrossRef]

160. Lao, X.; Feng, Q.; He, G.; Ji, M.; Zhu, D.; Xu, P.; Tang, W.; Xu, J.; Qin, X. Immature Colon Carcinoma Transcript-1 (ICT1) Expression Correlates with Unfavorable Prognosis and Survival in Patients with Colorectal Cancer. Ann. Surg. Oncol. 2016, 23, 3924-3933. [CrossRef]

161. Wang, Y.; He, J.; Zhang, S.; Yang, Q.; Wang, B.; Liu, Z.; Wu, X. Knockdown of Immature Colon Carcinoma Transcript 1 Inhibits Proliferation and Promotes Apoptosis of Non-Small Cell Lung Cancer Cells. Technol. Cancer Res. Treat. 2017, 16, 559-569. [CrossRef] [PubMed]

162. Wang, C.; Liang, C.; Feng, W.; Xia, X.; Chen, F.; Qiao, E.; Zhang, X.; Chen, D.; Ling, Z.; Yang, H. ICT1 knockdown inhibits breast cancer cell growth via induction of cell cycle arrest and apoptosis. Int. J. Mol. Med. 2017, 39, 1037-1045. [CrossRef]

163. Tao, Y.; Song, Y.; Han, T.; Wang, C.; Zhao, T.; Gu, Y. miR-205 regulation of ICT1 has an oncogenic potential via promoting the migration and invasion of gastric cancer cells. Biomed. Pharmacother. 2017, 96, 191-197. [CrossRef]

164. Xu, C.; Li, M.; Zhang, L.; Bi, Y.; Wang, P.; Li, J.; Jiang, X. MicroRNA-205 suppresses the invasion and epithelial-mesenchymal transition of human gastric cancer cells. Mol. Med. Rep. 2016, 13, 4767-4773. [CrossRef]

165. Keckesova, Z.; Donaher, J.L.; De Cock, J.; Freinkman, E.; Lingrell, S.; Bachovchin, D.A.; Bierie, B.; Tischler, V.; Noske, A.; Okondo, M.C.; et al. LACTB is a tumour suppressor that modulates lipid metabolism and cell state. Nature 2017, 543, 681-686. [CrossRef]

166. Xue, C.; He, Y.; Zhu, W.; Chen, X.; Yu, Y.; Hu, Q.; Chen, J.; Liu, L.; Ren, F.; Ren, Z.; et al. Low expression of LACTB promotes tumor progression and predicts poor prognosis in hepatocellular carcinoma. Am. J. Transl. Res. 2018, 10, 4152-4162.

167. Langer, Y.; Aran, A.; Gulsuner, S.; Abu Libdeh, B.; Renbaum, P.; Brunetti, D.; Teixeira, P.F.; Walsh, T.; Zeligson, S.; Ruotolo, R.; et al. Mitochondrial PITRM1 peptidase loss-of-function in childhood cerebellar atrophy. J. Med. Genet. 2018, 55, 599-606. [CrossRef]

168. Zhou, W.; Feng, X.; Li, H.; Wang, L.; Zhu, B.; Liu, W.; Zhao, M.; Yao, K.; Ren, C. Inactivation of LARS2, located at the commonly deleted region 3p21.3, by both epigenetic and genetic mechanisms in nasopharyngeal carcinoma. Acta Biochim. Biophys. Sin. 2009, 41, 54-62. [CrossRef]

169. Richter, M.; Wohlfromm, F.; Kähne, T.; Bongartz, H.; Seyrek, K.; Kit, Y.; Chinak, O.; Richter, V.A.; Koval, O.A.; Lavrik, I.N. The Recombinant Fragment of Human K-Casein Induces Cell Death by Targeting the Proteins of Mitochondrial Import in Breast Cancer Cells. Cancers 2020, 12, 1427. [CrossRef] 
170. Basch, M.; Wagner, M.; Rolland, S.; Carbonell, A.; Zeng, R.; Khosravi, S.; Schmidt, A.; Aftab, W.; Imhof, A.; Wagener, J.; et al. Msp1 cooperates with the proteasome for extraction of arrested mitochondrial import intermediates. Mol. Biol. Cell 2020, 31, 753-767. [CrossRef]

171. Poulogiannis, G.; McIntyre, R.E.; Dimitriadi, M.; Apps, J.R.; Wilson, C.H.; Ichimura, K.; Luo, F.; Cantley, L.C.; Wyllie, A.H.; Adams, D.J.; et al. PARK2 deletions occur frequently in sporadic colorectal cancer and accelerate adenoma development in $A p c$ mutant mice. Proc. Natl. Acad. Sci. USA 2010, 107, 15145-15150. [CrossRef]

172. Veeriah, S.; Taylor, B.S.; Meng, S.; Fang, F.; Yilmaz, E.; Vivanco, I.; Janakiraman, M.; Schultz, N.; Hanrahan, A.J.; Pao, W.; et al. Somatic mutations of the Parkinson's disease-associated gene PARK2 in glioblastoma and other human malignancies. Nat. Genet. 2010, 42, 77-82. [CrossRef]

173. Zhang, C.; Lin, M.; Wu, R.; Wang, X.; Yang, B.; Levine, A.J.; Hu, W.; Feng, Z. Parkin, a p53 target gene, mediates the role of p53 in glucose metabolism and the Warburg effect. Proc. Natl. Acad. Sci. USA 2011, 108, 16259-16264. [CrossRef]

174. Daverey, A.; Levytskyy, R.M.; Stanke, K.M.; Viana, M.P.; Swenson, S.; Hayward, S.L.; Narasimhan, M.; Khalimonchuk, O.; Kidambi, S. Depletion of mitochondrial protease OMA1 alters proliferative properties and promotes metastatic growth of breast cancer cells. Sci. Rep. 2019, 9, 14746. [CrossRef] [PubMed]

175. Li, H.T.; Dong, D.Y.; Liu, Q.; Xu, Y.Q.; Chen, L. Overexpression of LACTB, a Mitochondrial Protein That Inhibits Proliferation and Invasion in Glioma Cells. Oncol. Res. 2019, 27, 423-429. [CrossRef]

176. Polianskyte, Z.; Peitsaro, N.; Dapkunas, A.; Liobikas, J.; Soliymani, R.; Lalowski, M.; Speer, O.; Seitsonen, J.; Butcher, S.; Cereghetti, G.M.; et al. LACTB is a filament-forming protein localized in mitochondria. Proc. Natl. Acad. Sci. USA 2009, 106, 18960-18965. [CrossRef] [PubMed]

177. Zeng, K.; Chen, X.; Hu, X.; Liu, X.; Xu, T.; Sun, H.; Pan, Y.; He, B.; Wang, S. LACTB, a novel epigenetic silenced tumor suppressor, inhibits colorectal cancer progression by attenuating MDM2-mediated p53 ubiquitination and degradation. Oncogene 2018, 37, 5534-5551. [CrossRef]

178. Dunning, A.M.; Michailidou, K.; Kuchenbaecker, K.B.; Thompson, D.; French, J.D.; Beesley, J.; Healey, C.S.; Kar, S.; Pooley, K.A.; Lopez-Knowles, E.; et al. Breast cancer risk variants at 6q25 display different phenotype associations and regulate ESR1, RMND1 and CCDC170. Nat. Genet. 2016, 48, 374-386. [CrossRef]

179. Janer, A.; Antonicka, H.; Lalonde, E.; Nishimura, T.; Sasarman, F.; Brown, G.K.; Brown, R.M.; Majewski, J.; Shoubridge, E.A. An RMND1 Mutation causes encephalopathy associated with multiple oxidative phosphorylation complex deficiencies and a mitochondrial translation defect. Am. J. Hum. Genet. 2012, 91, 737-743. [CrossRef]

180. Birk, A.V.; Liu, S.; Soong, Y.; Mills, W.; Singh, P.; Warren, J.D.; Seshan, S.V.; Pardee, J.D.; Szeto, H.H. The mitochondrial-targeted compound SS-31 re-energizes ischemic mitochondria by interacting with cardiolipin. J. Am. Soc. Nephrol. 2013, 24, $1250-1261$. [CrossRef]

181. Liu, Z.; Dai, J.; Shen, H. Systematic analysis reveals long noncoding RNAs regulating neighboring transcription factors in human cancers. Biochim. Biophys. Acta Mol. Basis Dis. 2018, 1864, 2785-2792. [CrossRef] [PubMed]

182. Zurawa-Janicka, D.; Kobiela, J.; Galczynska, N.; Stefaniak, T.; Lipinska, B.; Lachinski, A.; Skorko-Glonek, J.; Narkiewicz, J.; Proczko-Markuszewska, M.; Sledzinski, Z. Changes in expression of human serine protease HtrA1, HtrA2 and HtrA3 genes in benign and malignant thyroid tumors. Oncol. Rep. 2012, 28, 1838-1844. [CrossRef] [PubMed]

183. Lee, S.H.; Lee, J.W.; Kim, H.S.; Kim, S.Y.; Park, W.S.; Kim, S.H.; Lee, J.Y.; Yoo, N.J. Immunohistochemical analysis of Omi/HtrA2 expression in stomach cancer. APMIS 2003, 111, 586-590. [CrossRef] [PubMed]

184. Mitra, A.; Shevde, L.A.; Samant, R.S. Multi-faceted role of HSP40 in cancer. Clin. Exp. Metastasis 2009, 26, 559-567. [CrossRef]

185. Wu, J.; Liu, T.; Rios, Z.; Mei, Q.; Lin, X.; Cao, S. Heat Shock Proteins and Cancer. Trends Pharmacol. Sci. 2017, 38, 226-256. [CrossRef]

186. Yun, C.W.; Kim, H.J.; Lim, J.H.; Lee, S.H. Heat Shock Proteins: Agents of Cancer Development and Therapeutic Targets in Anti-Cancer Therapy. Cells 2019, 9, 60. [CrossRef] [PubMed]

187. Oka, M.; Sato, S.; Soda, H.; Fukuda, M.; Kawabata, S.; Nakatomi, K.; Shiozawa, K.; Nakamura, Y.; Ohtsuka, K.; Kohno, S. Autoantibody to heat shock protein Hsp40 in sera of lung cancer patients. Jpn J. Cancer Res. 2001, 92, 316-320. [CrossRef]

188. Kanazawa, Y.; Isomoto, H.; Oka, M.; Yano, Y.; Soda, H.; Shikuwa, S.; Takeshima, F.; Omagari, K.; Mizuta, Y.; Murase, K.; et al. Expression of heat shock protein (Hsp) 70 and Hsp 40 in colorectal cancer. Med. Oncol. 2003, 20, 157-164. [CrossRef]

189. Acun, T.; Doberstein, N.; Habermann, J.K.; Gemoll, T.; Thorns, C.; Oztas, E.; Ried, T. HLJ1 (DNAJB4) Gene Is a Novel Biomarker Candidate in Breast Cancer. OMICS 2017, 21, 257-265. [CrossRef]

190. Cappello, F.; Marino Gammazza, A.; Palumbo Piccionello, A.; Campanella, C.; Pace, A.; Conway de Macario, E.; Macario, A.J. Hsp60 chaperonopathies and chaperonotherapy: Targets and agents. Expert Opin. Ther. Targets 2014, 18, 185-208. [CrossRef]

191. Cheng, M.Y.; Hartl, F.U.; Martin, J.; Pollock, R.A.; Kalousek, F.; Neuper, W.; Hallberg, E.M.; Hallberg, R.L.; Horwich, A.L. Mitochondrial heat-shock protein hsp60 is essential for assembly of proteins imported into yeast mitochondria. Nature 1989, 337, 620-625. [CrossRef]

192. Ghosh, J.C.; Dohi, T.; Kang, B.H.; Altieri, D.C. Hsp60 Regulation of Tumor Cell Apoptosis. J. Biol. Chem. 2008, $283,5188-5194$. [CrossRef]

193. Samali, A.; Cai, J.; Zhivotovsky, B.; Jones, D.P.; Orrenius, S. Presence of a pre-apoptotic complex of pro-caspase-3, Hsp60 and Hsp10 in the mitochondrial fraction of jurkat cells. EMBO J. 1999, 18, 2040-2048. [CrossRef] 
194. Tsai, Y.-P.; Teng, S.-C.; Wu, K.-J. Direct regulation of HSP60 expression by c-MYC induces transformation. FEBS Lett. 2008, 582, 4083-4088. [CrossRef]

195. Wiechmann, K.; Muller, H.; Konig, S.; Wielsch, N.; Svatos, A.; Jauch, J.; Werz, O. Mitochondrial Chaperonin HSP60 Is the Apoptosis-Related Target for Myrtucommulone. Cell Chem. Biol. 2017, 24, 614-623. [CrossRef]

196. Zhang, J.; Zhou, X.; Chang, H.; Huang, X.; Guo, X.; Du, X.; Tian, S.; Wang, L.; Lyv, Y.; Yuan, P.; et al. Hsp60 exerts a tumor suppressor function by inducing cell differentiation and inhibiting invasion in hepatocellular carcinoma. Oncotarget 2016, 7, 68976-68989. [CrossRef]

197. Zhou, C.; Sun, H.; Zheng, C.; Gao, J.; Fu, Q.; Hu, N.; Shao, X.; Zhou, Y.; Xiong, J.; Nie, K.; et al. Oncogenic HSP60 regulates mitochondrial oxidative phosphorylation to support Erk1/2 activation during pancreatic cancer cell growth. Cell Death Dis. 2018, 9, 161. [CrossRef]

198. Coates, P.J.; Nenutil, R.; McGregor, A.; Picksley, S.M.; Crouch, D.H.; Hall, P.A.; Wright, E.G. Mammalian prohibitin proteins respond to mitochondrial stress and decrease during cellular senescence. Exp. Cell Res. 2001, 265, 262-273. [CrossRef]

199. Leal, M.F.; Cirilo, P.D.R.; Mazzotti, T.K.F.; Calcagno, D.Q.; Wisnieski, F.; Demachki, S.; Martinez, M.C.; Assumpção, P.P.; Chammas, R.; Burbano, R.R.; et al. Prohibitin Expression Deregulation in Gastric Cancer Is Associated with the $3^{\prime}$ Untranslated Region 1630 C>T Polymorphism and Copy Number Variation. PLoS ONE 2014, 9, e98583. [CrossRef]

200. Yan, C.; Gong, L.; Chen, L.; Xu, M.; Abou-Hamdan, H.; Tang, M.; Désaubry, L.; Song, Z. PHB2 (prohibitin 2) promotes PINK1-PRKN/Parkin-dependent mitophagy by the PARL-PGAM5-PINK1 axis. Autophagy 2020, 16, 419-434. [CrossRef]

201. Yang, J.; Li, B.; He, Q.-Y. Significance of prohibitin domain family in tumorigenesis and its implication in cancer diagnosis and treatment. Cell Death Dis. 2018, 9, 580. [CrossRef]

202. Woo, Y.M.; Kim, S.; Park, J.H.; Lee, N.Y.; Kim, J.W.; Kim, D.D.H. Evidence that 6q25.1 variant rs6931104 confers susceptibility to chronic myeloid leukemia through RMND1 regulation. PLoS ONE 2019, 14, e0218968. [CrossRef]

203. Cole, A.; Wang, Z.; Coyaud, E.; Voisin, V.; Gronda, M.; Jitkova, Y.; Mattson, R.; Hurren, R.; Babovic, S.; Maclean, N.; et al. Inhibition of the Mitochondrial Protease ClpP as a Therapeutic Strategy for Human Acute Myeloid Leukemia. Cancer Cell 2015, 27, 864-876. [CrossRef]

204. Graves, P.R.; Aponte-Collazo, L.J.; Fennell, E.M.J.; Graves, A.C.; Hale, A.E.; Dicheva, N.; Herring, L.E.; Gilbert, T.S.K.; East, M.P.; McDonald, I.M.; et al. Mitochondrial Protease ClpP is a Target for the Anticancer Compounds ONC201 and Related Analogues. ACS Chem. Biol. 2019, 14, 1020-1029. [CrossRef]

205. Ishizawa, J.; Zarabi, S.F.; Davis, R.E.; Halgas, O.; Nii, T.; Jitkova, Y.; Zhao, R.; St-Germain, J.; Heese, L.E.; Egan, G.; et al. Mitochondrial ClpP-Mediated Proteolysis Induces Selective Cancer Cell Lethality. Cancer Cell 2019, 35, 721-737. [CrossRef]

206. Luo, J.; Zeng, B.; Tao, C.; Lu, M.; Ren, G. ClpP regulates breast cancer cell proliferation, invasion and apoptosis by modulating the Src/PI3K/Akt signaling pathway. PeerJ 2020, 8, e8754. [CrossRef]

207. Szczepanowska, K.; Maiti, P.; Kukat, A.; Hofsetz, E.; Nolte, H.; Senft, K.; Becker, C.; Ruzzenente, B.; Hornig-Do, H.T.; Wibom, R.; et al. CLPP coordinates mitoribosomal assembly through the regulation of ERAL1 levels. EMBO J. 2016, 35, $2566-2583$. [CrossRef]

208. Wang, Q.; Li, M.; Gan, Y.; Jiang, S.; Qiao, J.; Zhang, W.; Fan, Y.; Shen, Y.; Song, Y.; Meng, Z.; et al. Mitochondrial Protein UQCRC1 is Oncogenic and a Potential Therapeutic Target for Pancreatic Cancer. Theranostics 2020, 10, 2141-2157. [CrossRef]

209. Ellinger, J.; Gromes, A.; Poss, M.; Bruggemann, M.; Schmidt, D.; Ellinger, N.; Tolkach, Y.; Dietrich, D.; Kristiansen, G.; Muller, S.C. Systematic expression analysis of the mitochondrial complex III subunits identifies UQCRC1 as biomarker in clear cell renal cell carcinoma. Oncotarget 2016, 7, 86490-86499. [CrossRef]

210. Li, W.; Wubulikasimu, G.; Zhao, X.; Wang, C.; Liu, R.; Wang, L.; Zhu, X.; Chen, Z. UQCRC1 downregulation is correlated with lymph node metastasis and poor prognosis in CRC. Eur. J. Surg. Oncol. 2019, 45, 1005-1010. [CrossRef]

211. Shang, Y.; Zhang, F.; Li, D.; Li, C.; Li, H.; Jiang, Y.; Zhang, D. Overexpression of UQCRC2 is correlated with tumor progression and poor prognosis in colorectal cancer. Pathol Res. Pract 2018, 214, 1613-1620. [CrossRef]

212. Bai, Y.H.; Zhan, Y.B.; Yu, B.; Wang, W.W.; Wang, L.; Zhou, J.Q.; Chen, R.K.; Zhang, F.J.; Zhao, X.W.; Duan, W.C.; et al. A Novel Tumor-Suppressor, CDH18, Inhibits Glioma Cell Invasiveness Via UQCRC2 and Correlates with the Prognosis of Glioma Patients. Cell Physiol. Biochem. 2018, 48, 1755-1770. [CrossRef]

213. Zuiderweg, E.R.; Hightower, L.E.; Gestwicki, J.E. The remarkable multivalency of the Hsp70 chaperones. Cell Stress Chaperones 2017, 22, 173-189. [CrossRef]

214. Jego, G.; Hazoumé, A.; Seigneuric, R.; Garrido, C. Targeting heat shock proteins in cancer. Cancer Lett. 2013, 332, $275-285$. [CrossRef]

215. Kondrikov, D.; Fulton, D.; Dong, Z.; Su, Y. Heat Shock Protein 70 Prevents Hyperoxia-Induced Disruption of Lung Endothelial Barrier via Caspase-Dependent and AIF-Dependent Pathways. PLoS ONE 2015, 10, e0129343. [CrossRef]

216. Beere, H.M.; Wolf, B.B.; Cain, K.; Mosser, D.D.; Mahboubi, A.; Kuwana, T.; Tailor, P.; Morimoto, R.I.; Cohen, G.M.; Green, D.R. Heat-shock protein 70 inhibits apoptosis by preventing recruitment of procaspase-9 to the Apaf-1 apoptosome. Nat. Cell Biol. 2000, 2, 469-475. [CrossRef] [PubMed]

217. Pang, Q.; Christianson, T.A.; Keeble, W.; Koretsky, T.; Bagby, G.C. The anti-apoptotic function of Hsp70 in the interferon-inducible double-stranded RNA-dependent protein kinase-mediated death signaling pathway requires the Fanconi anemia protein, FANCC. J. Biol. Chem. 2002, 277, 49638-49643. [CrossRef] 
218. Boudesco, C.; Cause, S.; Jego, G.; Garrido, C. Hsp70: A Cancer Target Inside and Outside the Cell. Methods Mol. Biol. 2018, 1709, 371-396.

219. Guo, F.; Sigua, C.; Bali, P.; George, P.; Fiskus, W.; Scuto, A.; Annavarapu, S.; Mouttaki, A.; Sondarva, G.; Wei, S.; et al. Mechanistic role of heat shock protein 70 in Bcr-Abl-mediated resistance to apoptosis in human acute leukemia cells. Blood 2005, 105, 1246-1255. [CrossRef]

220. Li, J.; Buchner, J. Structure, function and regulation of the hsp90 machinery. Biomed J. 2013, 36, $106-117$.

221. Graner, M.W. HSP90 and Immune Modulation in Cancer. Adv. Cancer Res. 2016, 129, 191-224.

222. Tukaj, S.; Bieber, K.; Kleszczyński, K.; Witte, M.; Cames, R.; Kalies, K.; Zillikens, D.; Ludwig, R.J.; Fischer, T.W.; Kasperkiewicz, M. Topically Applied Hsp90 Blocker 17AAG Inhibits Autoantibody-Mediated Blister-Inducing Cutaneous Inflammation. J. Investig. Dermatol. 2017, 137, 341-349. [CrossRef] [PubMed]

223. Taiyab, A.; Sreedhar, A.S.; Rao, C.M. Hsp90 inhibitors, GA and 17AAG, lead to ER stress-induced apoptosis in rat histiocytoma. Biochem. Pharmacol. 2009, 78, 142-152. [CrossRef]

224. Jolly, C.; Morimoto, R.I. Role of the heat shock response and molecular chaperones in oncogenesis and cell death. J. Natl. Cancer Inst. 2000, 92, 1564-1572. [CrossRef] [PubMed]

225. Calderwood, S.K.; Khaleque, M.A.; Sawyer, D.B.; Ciocca, D.R. Heat shock proteins in cancer: Chaperones of tumorigenesis. Trends Biochem. Sci. 2006, 31, 164-172. [CrossRef]

226. Kaul, S.C.; Deocaris, C.C.; Wadhwa, R. Three faces of mortalin: A housekeeper, guardian and killer. Exp. Gerontol. 2007, 42, 263-274. [CrossRef] [PubMed]

227. Na, Y.; Kaul, S.C.; Ryu, J.; Lee, J.S.; Ahn, H.M.; Kaul, Z.; Kalra, R.S.; Li, L.; Widodo, N.; Yun, C.O.; et al. Stress chaperone mortalin contributes to epithelial-mesenchymal transition and cancer metastasis. Cancer Res. 2016, 76, 2754-2765. [CrossRef]

228. Wadhwa, R.; Takano, S.; Kaur, K.; Deocaris, C.C.; Pereira-Smith, O.M.; Reddel, R.R.; Kaul, S.C. Upregulation of mortalin/mthsp70/Grp75 contributes to human carcinogenesis. Int. J. Cancer 2006, 118, 2973-2980. [CrossRef]

229. Koc, E.C.; Burkhart, W.; Blackburn, K.; Moyer, M.B.; Schlatzer, D.M.; Moseley, A.; Spremulli, L.L. The large subunit of the mammalian mitochondrial ribosome. Analysis of the complement of ribosomal proteins present. J. Biol. Chem. 2001, 276, 43958-43969. [CrossRef] [PubMed]

230. Allard, P.; Rak, A.V.; Wimberly, B.T.; Clemons, W.M., Jr.; Kalinin, A.; Helgstrand, M.; Garber, M.B.; Ramakrishnan, V.; Härd, T. Another piece of the ribosome: Solution structure of S16 and its location in the 30S subunit. Structure 2000, 8, 875-882. [CrossRef]

231. Lamichhane, T.N.; Blewett, N.H.; Crawford, A.K.; Cherkasova, V.A.; Iben, J.R.; Begley, T.J.; Farabaugh, P.J.; Maraia, R.J. Lack of tRNA modification isopentenyl-A37 alters mRNA decoding and causes metabolic deficiencies in fission yeast. Mol. Cell Biol. 2013, 33, 2918-2929. [CrossRef] [PubMed]

232. Lamichhane, T.N.; Mattijssen, S.; Maraia, R.J. Human cells have a limited set of tRNA anticodon loop substrates of the tRNA isopentenyltransferase TRIT1 tumor suppressor. Mol. Cell Biol. 2013, 33, 4900-4908. [CrossRef] [PubMed]

233. Yarham, J.W.; Lamichhane, T.N.; Pyle, A.; Mattijssen, S.; Baruffini, E.; Bruni, F.; Donnini, C.; Vassilev, A.; He, L.; Blakely, E.L.; et al Defective i6A37 modification of mitochondrial and cytosolic tRNAs results from pathogenic mutations in TRIT1 and its substrate tRNA. PLoS Genet. 2014, 10, e1004424. [CrossRef]

234. Khalique, A.; Mattijssen, S.; Haddad, A.F.; Chaudhry, S.; Maraia, R.J. Targeting mitochondrial and cytosolic substrates of TRIT1 isopentenyltransferase: Specificity determinants and tRNA-i6A37 profiles. PLoS Genet. 2020, 16, e1008330. [CrossRef] [PubMed]

235. Smaldino, P.J.; Read, D.F.; Pratt-Hyatt, M.; Hopper, A.K.; Engelke, D.R. The cytoplasmic and nuclear populations of the eukaryote tRNA-isopentenyl transferase have distinct functions with implications in human cancer. Gene 2015, 556, 13-18. [CrossRef]

236. Spinola, M.; Falvella, F.S.; Galvan, A.; Pignatiello, C.; Leoni, V.P.; Pastorino, U.; Paroni, R.; Chen, S.; Skaug, V.; Haugen, A.; et al. Ethnic differences in frequencies of gene polymorphisms in the MYCL1 region and modulation of lung cancer patients' survival. Lung Cancer 2007, 55, 271-277. [CrossRef]

237. Spinola, M.; Galvan, A.; Pignatiello, C.; Conti, B.; Pastorino, U.; Nicander, B.; Paroni, R.; Dragani, T.A. Identification and functional characterization of the candidate tumor suppressor gene TRIT1 in human lung cancer. Oncogene 2005, 24, 5502-5509. [CrossRef]

238. Waller, T.J.; Read, D.F.; Engelke, D.R.; Smaldino, P.J. The human tRNA-modifying protein, TRIT1, forms amyloid fibers in vitro Gene 2017, 612, 19-24. [CrossRef]

239. Pickrell, A.M.; Youle, R.J. The roles of PINK1, parkin, and mitochondrial fidelity in Parkinson's disease. Neuron 2015, 85, 257-273. [CrossRef]

240. Bernardini, J.P.; Lazarou, M.; Dewson, G. Parkin and mitophagy in cancer. Oncogene 2017, 36, 1315-1327. [CrossRef]

241. Matsuda, S.; Nakanishi, A.; Minami, A.; Wada, Y.; Kitagishi, Y. Functions and characteristics of PINK1 and Parkin in cancer. Front Biosci. 2015, 20, 491-501. [CrossRef]

242. Lee, S.; Schmitt, C.A. The dynamic nature of senescence in cancer. Nat. Cell Biol. 2019, 21, 94-101. [CrossRef] [PubMed]

243. Liu, J.; Zhang, C.; Zhao, Y.; Yue, X.; Wu, H.; Huang, S.; Chen, J.; Tomsky, K.; Xie, H.; Khella, C.A.; et al. Parkin targets HIF-1alpha for ubiquitination and degradation to inhibit breast tumor progression. Nat. Commun. 2017, 8, 1823. [CrossRef]

244. Mendivil-Perez, M.; Jimenez-Del-Rio, M.; Velez-Pardo, C. Response to rotenone is glucose-sensitive in a model of human acute lymphoblastic leukemia: Involvement of oxidative stress mechanism, DJ-1, Parkin, and PINK-1 proteins. Oxid. Med. Cell. Longev. 2014, 2014, 457154. [CrossRef]

245. Yao, N.; Wang, C.; Hu, N.; Li, Y.; Liu, M.; Lei, Y.; Chen, M.; Chen, L.; Chen, C.; Lan, P.; et al. Inhibition of PINK1/Parkin-dependent mitophagy sensitizes multidrug-resistant cancer cells to B5G1, a new betulinic acid analog. Cell Death Dis. 2019, 10, 232. [CrossRef] 
246. Zhang, J.; He, Y.; Yu, Y.; Chen, X.; Cui, G.; Wang, W.; Zhang, X.; Luo, Y.; Li, J.; Ren, F.; et al. Upregulation of miR-374a promotes tumor metastasis and progression by downregulating LACTB and predicts unfavorable prognosis in breast cancer. Cancer Med. 2018. [CrossRef]

247. Head, B.; Griparic, L.; Amiri, M.; Gandre-Babbe, S.; van der Bliek, A.M. Inducible proteolytic inactivation of OPA1 mediated by the OMA1 protease in mammalian cells. J. Cell Biol. 2009, 187, 959-966. [CrossRef]

248. Deshwal, S.; Fiedler, K.U.; Langer, T. Mitochondrial Proteases: Multifaceted Regulators of Mitochondrial Plasticity. Annu. Rev. Biochem. 2020, 89, 501-528. [CrossRef]

249. MacVicar, T.; Langer, T. OPA1 processing in cell death and disease-The long and short of it. J. Cell Sci. 2016, 129, 2297-2306. [CrossRef]

250. Alavi, M.V. Targeted OMA1 therapies for cancer. Int. J. Cancer 2019, 145, 2330-2341. [CrossRef]

251. Silic-Benussi, M.; Scattolin, G.; Cavallari, I.; Minuzzo, S.; Del Bianco, P.; Francescato, S.; Basso, G.; Indraccolo, S.; D'Agostino, D.M.; Ciminale, V. Selective killing of human T-ALL cells: An integrated approach targeting redox homeostasis and the OMA1/OPA1 axis. Cell Death Dis. 2018, 9, 822. [CrossRef]

252. Jang, J.Y.; Choi, Y.; Jeon, Y.K.; Aung, K.C.; Kim, C.W. Over-expression of adenine nucleotide translocase 1 (ANT1) induces apoptosis and tumor regression in vivo. BMC Cancer 2008, 8, 160. [CrossRef]

253. Sharer, J.D. The adenine nucleotide translocase type 1 (ANT1): A new factor in mitochondrial disease. IUBMB Life 2005, 57, 607-614. [CrossRef]

254. Vial, J.; Huchede, P.; Fagault, S.; Basset, F.; Rossi, M.; Geoffray, J.; Soldati, H.; Bisaccia, J.; Elsensohn, M.H.; Creveaux, M.; et al. Low expression of ANT1 confers oncogenic properties to rhabdomyosarcoma tumor cells by modulating metabolism and death pathways. Cell Death Discov. 2020, 6, 64. [CrossRef]

255. t Hart, L.M.; Hansen, T.; Rietveld, I.; Dekker, J.M.; Nijpels, G.; Janssen, G.M.; Arp, P.A.; Uitterlinden, A.G.; Jorgensen, T.; Borch-Johnsen, K.; et al. Evidence that the mitochondrial leucyl tRNA synthetase (LARS2) gene represents a novel type 2 diabetes susceptibility gene. Diabetes 2005, 54, 1892-1895. [CrossRef]

256. Weiss, D.; Basel, T.; Sachse, F.; Braeuninger, A.; Rudack, C. Promoter methylation of cyclin A1 is associated with human papillomavirus 16 induced head and neck squamous cell carcinoma independently of p53 mutation. Mol. Carcinog 2011, 50, 680-688. [CrossRef]

257. Lazarou, M.; Jin, S.M.; Kane, L.A.; Youle, R.J. Role of PINK1 binding to the TOM complex and alternate intracellular membranes in recruitment and activation of the E3 ligase Parkin. Dev. Cell 2012, 22, 320-333. [CrossRef]

258. Kreimendahl, S.; Rassow, J. The Mitochondrial Outer Membrane Protein Tom70-Mediator in Protein Traffic, Membrane Contact Sites and Innate Immunity. Int. J. Mol. Sci. 2020, 21, 7262. [CrossRef] [PubMed]

259. Umemoto, T.; Asai, T.; Hirashima, K.; Shimizu, K.; Mihara, M.; Yamamoto, K.; Kubota, K.; Miyagawa, S.; Oku, N. Proapoptotic action of p53-Tom5 in p53-resistant A549 human non-small cell lung cancer cells through direct mitochondrial dysfunction. Biol. Pharm. Bull. 2011, 34, 551-554. [CrossRef]

260. Zhou, B.; Zhang, J.Y.; Liu, X.S.; Chen, H.Z.; Ai, Y.L.; Cheng, K.; Sun, R.Y.; Zhou, D.; Han, J.; Wu, Q. Tom20 senses iron-activated ROS signaling to promote melanoma cell pyroptosis. Cell Res. 2018, 28, 1171-1185. [CrossRef]

261. Fan, F.; Duan, Y.; Yang, F.; Trexler, C.; Wang, H.; Huang, L.; Li, Y.; Tang, H.; Wang, G.; Fang, X.; et al. Deletion of heat shock protein 60 in adult mouse cardiomyocytes perturbs mitochondrial protein homeostasis and causes heart failure. Cell Death Differ. 2020, 27, 587-600. [CrossRef] [PubMed]

262. Cappello, F.; David, S.; Rappa, F.; Bucchieri, F.; Marasa, L.; Bartolotta, T.E.; Farina, F.; Zummo, G. The expression of HSP60 and HSP10 in large bowel carcinomas with lymph node metastase. BMC Cancer 2005, 5, 139. [CrossRef]

263. Anderson, C.J.; Kahl, A.; Fruitman, H.; Qian, L.; Zhou, P.; Manfredi, G.; Iadecola, C. Prohibitin levels regulate OMA1 activity and turnover in neurons. Cell Death Differ. 2020, 27, 1896-1906. [CrossRef]

264. Fusaro, G.; Dasgupta, P.; Rastogi, S.; Joshi, B.; Chellappan, S. Prohibitin induces the transcriptional activity of p53 and is exported from the nucleus upon apoptotic signaling. J. Biol. Chem. 2003, 278, 47853-47861. [CrossRef]

265. Wang, S.; Faller, D.V. Roles of prohibitin in growth control and tumor suppression in human cancers. Transl. Oncogenom. 2008, 3, 23-37.

266. Moreno-Cinos, C.; Goossens, K.; Salado, I.G.; Van Der Veken, P.; De Winter, H.; Augustyns, K. ClpP Protease, a Promising Antimicrobial Target. Int. J. Mol. Sci. 2019, 20, 2232. [CrossRef] [PubMed]

267. Bulteau, A.L.; Bayot, A. Mitochondrial proteases and cancer. Biochim. Biophys. Acta 2011, 1807, 595-601. [CrossRef]

268. Nishigaki, R.; Osaki, M.; Hiratsuka, M.; Toda, T.; Murakami, K.; Jeang, K.T.; Ito, H.; Inoue, T.; Oshimura, M. Proteomic identification of differentially-expressed genes in human gastric carcinomas. Proteomics 2005, 5, 3205-3213. [CrossRef]

269. Fernandez-Vizarra, E.; Zeviani, M. Mitochondrial complex III Rieske Fe-S protein processing and assembly. Cell Cycle 2018, 17, 681-687. [CrossRef]

270. Yan, C.; Li, T.S. Dual Role of Mitophagy in Cancer Drug Resistance. Anticancer Res. 2018, 38, 617-621.

271. Mellatyar, H.; Talaei, S.; Pilehvar-Soltanahmadi, Y.; Barzegar, A.; Akbarzadeh, A.; Shahabi, A.; Barekati-Mowahed, M.; Zarghami, N. Targeted cancer therapy through 17-DMAG as an Hsp90 inhibitor: Overview and current state of the art. Biomed. Pharmacother. 2018, 102, 608-617. [CrossRef] 
272. Smith, M.A.; Morton, C.L.; Phelps, D.A.; Kolb, E.A.; Lock, R.; Carol, H.; Reynolds, C.P.; Maris, J.M.; Keir, S.T.; Wu, J.; et al. Stage 1 testing and pharmacodynamic evaluation of the HSP90 inhibitor alvespimycin (17-DMAG, KOS-1022) by the pediatric preclinical testing program. Pediatr. Blood Cancer 2008, 51, 34-41. [CrossRef] [PubMed]

273. Wang, H.; Bu, L.; Wang, C.; Zhang, Y.; Zhou, H.; Zhang, X.; Guo, W.; Long, C.; Guo, D.; Sun, X. The Hsp70 inhibitor 2phenylethynesulfonamide inhibits replication and carcinogenicity of Epstein-Barr virus by inhibiting the molecular chaperone function of Hsp70. Cell Death Dis. 2018, 9, 734. [CrossRef]

274. Zeng, F.; Tee, C.; Liu, M.; Sherry, J.P.; Dixon, B.; Duncker, B.P.; Bols, N.C. The p53/HSP70 inhibitor, 2-phenylethynesulfonamide, causes oxidative stress, unfolded protein response and apoptosis in rainbow trout cells. Aquat. Toxicol. 2014, 146, 45-51. [CrossRef] [PubMed]

275. Park, H.K.; Lee, J.E.; Lim, J.; Jo, D.E.; Park, S.A.; Suh, P.G.; Kang, B.H. Combination treatment with doxorubicin and gamitrinib synergistically augments anticancer activity through enhanced activation of Bim. BMC Cancer 2014, 14, 431. [CrossRef]

276. Ajabnoor, G.M.A. Classical Taxane versus the New Generation, Nab-Paclitaxel Chemotherapy in the Treatment of Breast Cancer. MOJ Cell Sci. Rep. 2017, 4, 00086. [CrossRef]

277. Cheng, C.F.; Juan, S.H.; Chen, J.J.; Chao, Y.C.; Chen, H.H.; Lian, W.S.; Lu, C.Y.; Chang, C.I.; Chiu, T.H.; Lin, H. Pravastatin attenuates carboplatin-induced cardiotoxicity via inhibition of oxidative stress associated apoptosis. Apoptosis 2008, 13, 883-894. [CrossRef]

278. Ho, G.Y.; Woodward, N.; Coward, J.I. Cisplatin versus carboplatin: Comparative review of therapeutic management in solid malignancies. Crit. Rev. Oncol. Hematol. 2016, 102, 37-46. [CrossRef] [PubMed]

279. Kleih, M.; Bopple, K.; Dong, M.; Gaissler, A.; Heine, S.; Olayioye, M.A.; Aulitzky, W.E.; Essmann, F. Direct impact of cisplatin on mitochondria induces ROS production that dictates cell fate of ovarian cancer cells. Cell Death Dis. 2019, 10, 851. [CrossRef]

280. He, P.J.; Ge, R.F.; Mao, W.J.; Chung, P.S.; Ahn, J.C.; Wu, H.T. Oxidative stress induced by carboplatin promotes apoptosis and inhibits migration of HN-3 cells. Oncol. Lett. 2018, 16, 7131-7138. [CrossRef]

281. Shen, B.; Mao, W.; Ahn, J.C.; Chung, P.S.; He, P. Mechanism of HN3 cell apoptosis induced by carboplatin: Combination of mitochondrial pathway associated with Ca2+ and the nucleus pathways. Mol. Med. Rep. 2018, 18, 4978-4986.

282. Prabhu, V.V.; Morrow, S.; Rahman Kawakibi, A.; Zhou, L.; Ralff, M.; Ray, J.; Jhaveri, A.; Ferrarini, I.; Lee, Y.; Parker, C.; et al. ONC201 and imipridones: Anti-cancer compounds with clinical efficacy. Neoplasia 2020, 22, 725-744. [CrossRef]

283. Dando, T.M.; Wiseman, L.R. Clodronate: A review of its use in the prevention of bone metastases and the management of skeletal complications associated with bone metastases in patients with breast cancer. Drugs Aging 2004, 21, 949-962. [CrossRef]

284. Hurst, M.; Noble, S. Clodronate: A review of its use in breast cancer. Drugs Aging 1999, 15, 143-167. [CrossRef]

285. Lehenkari, P.P.; Kellinsalmi, M.; Napankangas, J.P.; Ylitalo, K.V.; Monkkonen, J.; Rogers, M.J.; Azhayev, A.; Vaananen, H.K.; Hassinen, I.E. Further insight into mechanism of action of clodronate: Inhibition of mitochondrial ADP/ATP translocase by a nonhydrolyzable, adenine-containing metabolite. Mol. Pharmacol. 2002, 61, 1255-1262. [CrossRef] [PubMed]

286. Fonseca, S.B.; Kelley, S.O. Peptide-chlorambucil conjugates combat pgp-dependent drug efflux. ACS Med. Chem. Lett. 2011, 2, 419-423. [CrossRef]

287. Fonseca, S.B.; Pereira, M.P.; Mourtada, R.; Gronda, M.; Horton, K.L.; Hurren, R.; Minden, M.D.; Schimmer, A.D.; Kelley, S.O. Rerouting chlorambucil to mitochondria combats drug deactivation and resistance in cancer cells. Chem. Biol. 2011, 18, 445-453. [CrossRef]

288. Pathak, R.K.; Wen, R.; Kolishetti, N.; Dhar, S. A Prodrug of Two Approved Drugs, Cisplatin and Chlorambucil, for Chemo War Against Cancer. Mol. Cancer Ther. 2017, 16, 625-636. [CrossRef]

289. Wang, Y.; Liu, H.H.; Cao, Y.T.; Zhang, L.L.; Huang, F.; Yi, C. The Role of Mitochondrial Dynamics and Mitophagy in Carcinogenesis, Metastasis and Therapy. Front. Cell Dev. Biol. 2020, 8, 413. [CrossRef]

290. Szeto, H.H. Mitochondria-targeted peptide antioxidants: Novel neuroprotective agents. AAPS J. 2006, 8, E521-E531. [CrossRef] [PubMed]

291. Leu, J.I.; Pimkina, J.; Frank, A.; Murphy, M.E.; George, D.L. A small molecule inhibitor of inducible heat shock protein 70. Mol. Cell 2009, 36, 15-27. [CrossRef] [PubMed]

292. Leu, J.I.; Pimkina, J.; Pandey, P.; Murphy, M.E.; George, D.L. HSP70 inhibition by the small-molecule 2-phenylethynesulfonamide impairs protein clearance pathways in tumor cells. Mol. Cancer Res. 2011, 9, 936-947. [CrossRef] [PubMed]

293. Propper, D.J.; Braybrooke, J.P.; Taylor, D.J.; Lodi, R.; Styles, P.; Cramer, J.A.; Collins, W.C.; Levitt, N.C.; Talbot, D.C.; Ganesan, T.S.; et al. Phase I trial of the selective mitochondrial toxin MKT077 in chemo-resistant solid tumours. Ann. Oncol. 1999, 10, 923-927. [CrossRef]

294. Wu, D.; Wang, Y.; Yang, G.; Zhang, S.; Liu, Y.; Zhou, S.; Guo, H.; Liang, S.; Cui, Y.; Zhang, B.; et al. A novel mitochondrial amidoxime reducing component 2 is a favorable indicator of cancer and suppresses the progression of hepatocellular carcinoma by regulating the expression of p27. Oncogene 2020, 39, 6099-6112. [CrossRef]

295. Deocaris, C.C.; Widodo, N.; Shrestha, B.G.; Kaur, K.; Ohtaka, M.; Yamasaki, K.; Kaul, S.C.; Wadhwa, R. Mortalin sensitizes human cancer cells to MKT-077-induced senescence. Cancer Lett. 2007, 252, 259-269. [CrossRef] [PubMed]

296. Prodromou, C.; Roe, S.M.; O’Brien, R.; Ladbury, J.E.; Piper, P.W.; Pearl, L.H. Identification and structural characterization of the ATP/ADP-binding site in the Hsp90 molecular chaperone. Cell 1997, 90, 65-75. [CrossRef] 
297. Egorin, M.J.; Lagattuta, T.F.; Hamburger, D.R.; Covey, J.M.; White, K.D.; Musser, S.M.; Eiseman, J.L. Pharmacokinetics, tissue distribution, and metabolism of 17-(dimethylaminoethylamino)-17-demethoxygeldanamycin (NSC 707545) in CD2F1 mice and Fischer 344 rats. Cancer Chemother. Pharmacol. 2002, 49, 7-19. [CrossRef] [PubMed]

298. Neckers, L. Heat shock protein 90: The cancer chaperone. J. Biosci. 2007, 32, 517-530. [CrossRef]

299. Kang, B.H.; Plescia, J.; Song, H.Y.; Meli, M.; Colombo, G.; Beebe, K.; Scroggins, B.; Neckers, L.; Altieri, D.C. Combinatorial drug design targeting multiple cancer signaling networks controlled by mitochondrial Hsp90. J. Clin. Investig. 2009, 119, 454-464. [CrossRef]

300. Kang, B.H.; Tavecchio, M.; Goel, H.L.; Hsieh, C.C.; Garlick, D.S.; Raskett, C.M.; Lian, J.B.; Stein, G.S.; Languino, L.R.; Altieri, D.C. Targeted inhibition of mitochondrial Hsp90 suppresses localised and metastatic prostate cancer growth in a genetic mouse model of disease. Br. J. Cancer 2011, 104, 629-634. [CrossRef]

301. Varbiro, G.; Veres, B.; Gallyas, F., Jr.; Sumegi, B. Direct effect of Taxol on free radical formation and mitochondrial permeability transition. Free Radic. Biol. Med. 2001, 31, 548-558. [CrossRef]

302. Byrd, C.A.; Bornmann, W.; Erdjument-Bromage, H.; Tempst, P.; Pavletich, N.; Rosen, N.; Nathan, C.F.; Ding, A. Heat shock protein 90 mediates macrophage activation by Taxol and bacterial lipopolysaccharide. Proc. Natl. Acad. Sci. USA 1999, 96, 5645-5650. [CrossRef] [PubMed]

303. Allen, J.E.; Krigsfeld, G.; Mayes, P.A.; Patel, L.; Dicker, D.T.; Patel, A.S.; Dolloff, N.G.; Messaris, E.; Scata, K.A.; Wang, W.; et al. Dual inactivation of Akt and ERK by TIC10 signals Foxo3a nuclear translocation, TRAIL gene induction, and potent antitumor effects. Sci. Transl. Med. 2013, 5, 171ra17. [CrossRef]

304. Dong, L.; Gopalan, V.; Holland, O.; Neuzil, J. Mitocans Revisited: Mitochondrial Targeting as Efficient Anti-Cancer Therapy. Int. J. Mol. Sci. 2020, 21, 7941. [CrossRef] [PubMed]

305. Kim, G.G.; Lee, J.Y.; Choi, P.S.; Kim, S.W.; Park, J.H. Tumor Targeting Effect of Triphenylphosphonium Cations and Folic Acid Coated with Zr-89-Labeled Silica Nanoparticles. Molecules 2020, 25, 2922. [CrossRef] [PubMed]

306. Ozsvari, B.; Sotgia, F.; Lisanti, M.P. Exploiting mitochondrial targeting signal(s), TPP and bis-TPP, for eradicating cancer stem cells (CSCs). Aging 2018, 10, 229-240. [CrossRef]

307. Biswas, S.; Dodwadkar, N.S.; Deshpande, P.P.; Torchilin, V.P. Liposomes loaded with paclitaxel and modified with novel triphenylphosphonium-PEG-PE conjugate possess low toxicity, target mitochondria and demonstrate enhanced antitumor effects in vitro and in vivo. J. Control. Release 2012, 159, 393-402. [CrossRef]

308. Biswas, S.; Dodwadkar, N.S.; Piroyan, A.; Torchilin, V.P. Surface conjugation of triphenylphosphonium to target poly(amidoamine) dendrimers to mitochondria. Biomaterials 2012, 33, 4773-4782. [CrossRef]

309. Li, Q.; Huang, Y. Mitochondrial targeted strategies and theirapplication for cancer and other diseases treatment. J. Pharm. Investig. 2020, 50, 271-293. [CrossRef]

310. Birk, A.V.; Chao, W.M.; Bracken, C.; Warren, J.D.; Szeto, H.H. Targeting mitochondrial cardiolipin and the cytochrome c/cardiolipin complex to promote electron transport and optimize mitochondrial ATP synthesis. Br. J. Pharmacol. 2014, 171, 2017-2028. [CrossRef]

311. Szeto, H.H. First-in-class cardiolipin-protective compound as a therapeutic agent to restore mitochondrial bioenergetics. $\mathrm{Br}$. J. Pharmacol. 2014, 171, 2029-2050. [CrossRef]

312. Shi, J.; Dai, W.; Hale, S.L.; Brown, D.A.; Wang, M.; Han, X.; Kloner, R.A. Bendavia restores mitochondrial energy metabolism gene expression and suppresses cardiac fibrosis in the border zone of the infarcted heart. Life Sci. 2015, 141, 170-178. [CrossRef]

313. Huang, Y.; You, X.; Wang, L.; Zhang, G.; Gui, S.; Jin, Y.; Zhao, R.; Zhang, D. Pyridinium-Substituted Tetraphenylethylenes Functionalized with Alkyl Chains as Autophagy Modulators for Cancer Therapy. Angew. Chem. Int. Ed. Engl. 2020, 59, 10042-10051. [CrossRef]

314. Xu, J.; He, H.; Zhou, L.J.; Liu, Y.Z.; Li, D.W.; Jiang, F.L.; Liu, Y. Pyridinium and indole orientation determines the mitochondrial uncoupling and anti-cancer efficiency of F16. Eur. J. Med. Chem. 2018, 154, 305-313. [CrossRef]

315. Hussain, S.; Du, W.; Zhang, M.; Fang, B.; Zhang, G.; Su, R.; Nan, K.; Zhang, Q.; Tian, X.; Tian, Y.; et al. A series of two-photon absorption pyridinium sulfonate inner salts targeting endoplasmic reticulum (ER), inducing cellular stress and mitochondriamediated apoptosis in cancer cells. J. Mater Chem. B 2018, 6, 1943-1950. [CrossRef] [PubMed]

316. Wang, Y.; Liu, T.; Zhang, E.; Luo, S.; Tan, X.; Shi, C. Preferential accumulation of the near infrared heptamethine dye IR-780 in the mitochondria of drug-resistant lung cancer cells. Biomaterials 2014, 35, 4116-4124. [CrossRef] [PubMed]

317. Thomas, A.P.; Palanikumar, L.; Jeena, M.T.; Kim, K.; Ryu, J.H. Cancer-mitochondria-targeted photodynamic therapy with supramolecular assembly of HA and a water soluble NIR cyanine dye. Chem. Sci. 2017, 8, 8351-8356. [CrossRef] [PubMed]

318. Momcilovic, M.; Jones, A.; Bailey, S.T.; Waldmann, C.M.; Li, R.; Lee, J.T.; Abdelhady, G.; Gomez, A.; Holloway, T.; Schmid, E.; et al. In vivo imaging of mitochondrial membrane potential in non-small-cell lung cancer. Nature 2019, 575, 380-384. [CrossRef] [PubMed] 